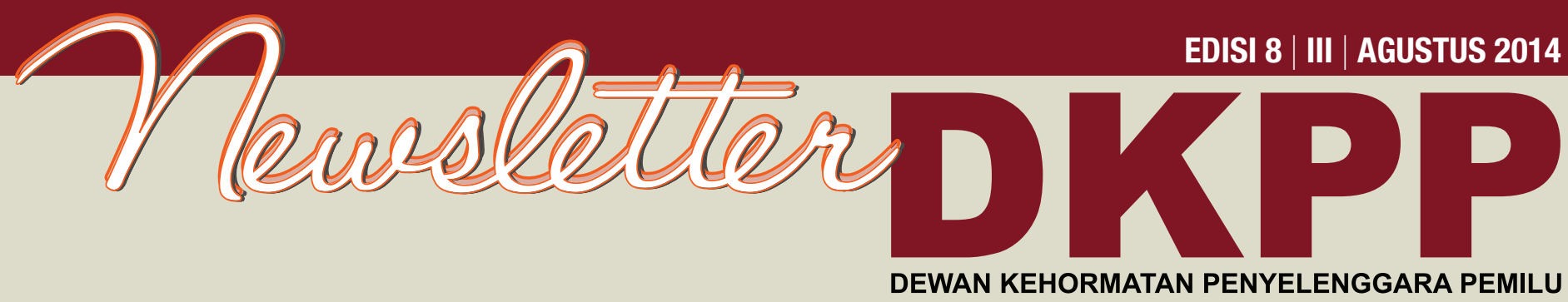

UNTUK KEMANDIRIAN, INTEGRITAS DAN KREDIBILITAS PENYELENGGARA PEMILU

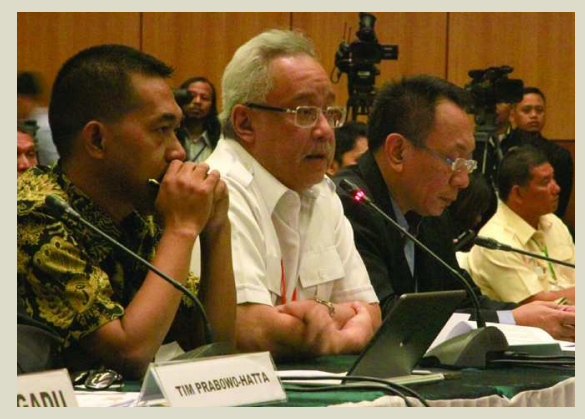

Kuliah Etika

BEBAN PENJARA SEBAGAI WAHANA RESOSIALISASI NARAPIDANA
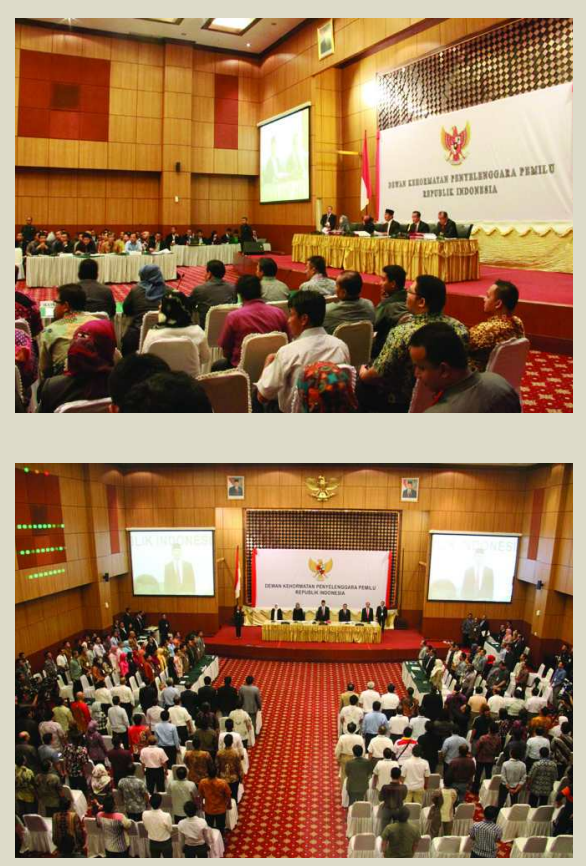

Kupas Tuntas

MENUNTASKAN PERKARA PILPRES

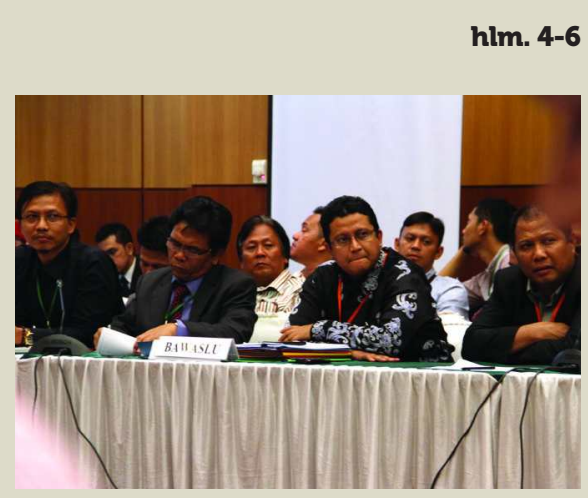

hlm. 14-15

Kolom Anggota

SATU ANGGOTA MAJELIS BERBEDA PENDAPAT

hlm. 13

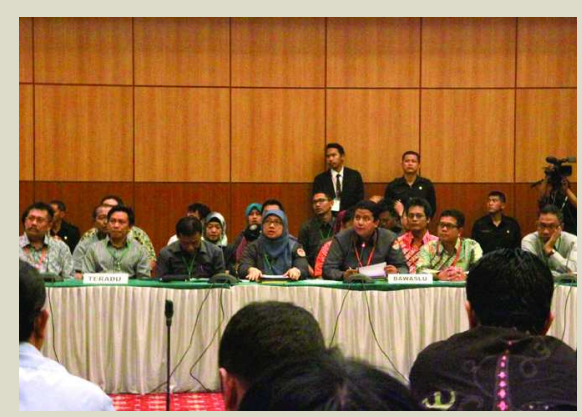

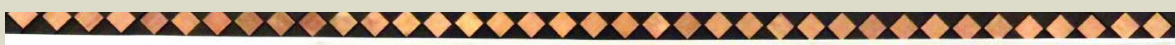

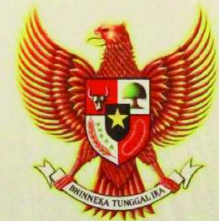

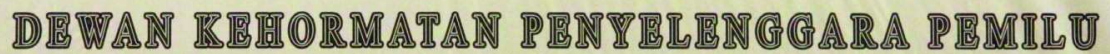
RISTORIR INDONISIA

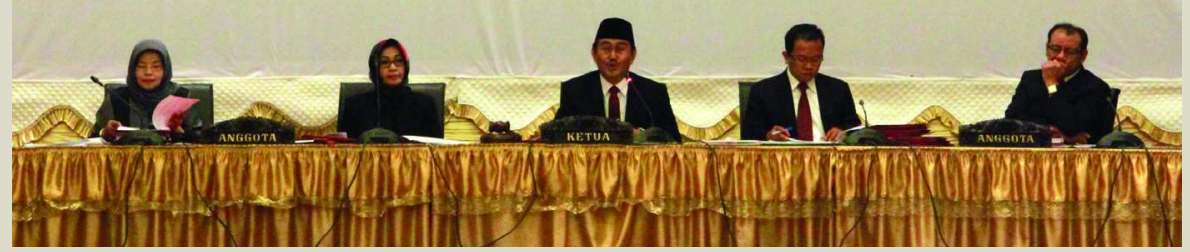




\section{Indonesia Patut Bangga}

P uji syukur kita panjatkan kepada Tuhan yang Maha Kuasa. Betapa tidak, pelaksanaan Pemilu baik Presiden sudah berjalan dengan lancar dan aman. Segala kekhawatiran, segala kecemasan, segala prasangka negatif pun sirna.

Pilpres 20I4 kali ini merupakan Pilres yang cukup menegangkan. Kedua pasangan calon saling memojokan. Kampanye tak hanya menjual visi dan misi melainkan perang urat saraf di antara dua kubu. Kampanye hitam di mana-mana. Masyarakat pun terpecah menjadi dua blok.

Begitu pungut hitung suara, ketegangan tidaklah reda. Justru tensi persaingan semakin menajam. Pasalnya, hasil pungut hitung (quick count) memiliki versi yang berbeda-beda. Kedua pasangan calong sama-sama saling mengklaim kemenangannya.

Kandidat yang tidak puas patut diacung jempol. Pasalnya, pasangan yang kalah tidak menempuh jalur-jalur anarkis. Mereka menempuh gugatan yang telah disediakan oleh negara.

Negara pun telah menyediakan sarana bagi pasangan calon yang tidak puas atas terhadap hasil pemilihan umum. Kekecewaan terhadap perilaku penyelenggara Pemilu, diadukan ke Dewan Kehormatan Penyelenggara Pemilu. Sedangkan kekecewaan terhadap hasil Pemilu, diajukan kepada Mahkamah Konstitusi.

Dewan Kehormatan Penyelenggara Pemilu pun menetapkan skala prioritas. Pengaduan terkait Pemilihan Presiden diutamakan terlebih dahulu. Pasalnya, ini berkaitan langsung dengan kepentingan seluruh masyarakat Indonesia. sidang hanya 2-3 jam. telah berakhir. tik pada era Orde Baru.

\section{Daftar Isi}

Warta DKPP

Ketua DKPP: Proses Hukum

Pilpres Sudah Selesai

hlm. 3

Kupas Tuntas

Menuntaskan Perkara Pilpres

hlm. 4-6

Kolom Anggota

Satu Anggota Majelis Berbeda

Pendapat

hlm. 7

DKPP sampai menggelar lima kali sidang terkait Pilpres. Siang dan malam. Pelaksanaan sidang ini merupakan sidang terlama. Biasanya, DKPP menggelar sidang hanya satu sampai tiga kali sidang dalam setiap perkara. Setiap kali

Pelaksanaan persidangan berjalan lancar. Seluruh pengunjung, pihak terkait mengikuti proses persidangan dengan tertib. Bahkan ketika sampai pembacaan Putusan yang waktunya berbarengan dengan jadwal pembacaan Putusan di Mahkamah Konstitusi tidak ada gejolak. Seluruh pihak menerima Putusan DKPP termasuk juga Putusan di MK. Ini artinya, seluruh permasalahan terkait dengan Pilpres

Dengan menerimanya Putusan ini, tingkat kematangan dan kedewasaan dalam berdemokrasi sudah meningkat. Dan bangsa Indonesia patut berbangga karena telah melakukan proses suksesi kepemimpinan dengan lancar. Indonesia berhak menyandang sebagai negara yang melaksanakan demokrasi secara penuh bukan lagi demokrasi formalis-

Dengan berakhirnya putusan itu, berakhir pula segala permasalahan. Pemenang Pemilu adalah pasangan Jokowi-Kalla. Ini sebagai pertanda bahwa pasangan ini secara sah menjadi presiden Indonesia terpilih ketujuh. Dan pasangan ini wajib dilantik oleh MPR sebagai calon terpilih. Selamat kepada pasangan Jokowi-Kalla!
Ragam

Menyaksikan Sidang, Pengunjung Rela Lesehan

hlm. 8

Aneka Barang-Barang Pengunjung Sidang Pilpres

hlm. 9

\section{Mereka Bicara}

Problematik Pemeriksaan Pelanggaran Kode Etik Penyelenggara Pemilihan Umum

hlm. Io

Perspektif

DKPP Kanalisasi Kekecewaan Masyarakat Terhadap Pelanggaran Kode Etik Penyelenggara Pemilu

hlm. II

Ketok Palu

KPU Disanksi, KPU Dipuji

hlm. I2

Sisi Lain

Tim Putra-Putri DKPP Juara Tarik Tambang

hlm. I3

Kuliah Etika

Beban Penjara Sebagai Wahana

Resosialisasi Narapidana

hlm. I4-I5

Parade Foto

hlm. I6 


\section{Warta DKPP}

\section{Ketua DKPP: Proses Hukum}

\section{Pilpres Sudah Selesai}

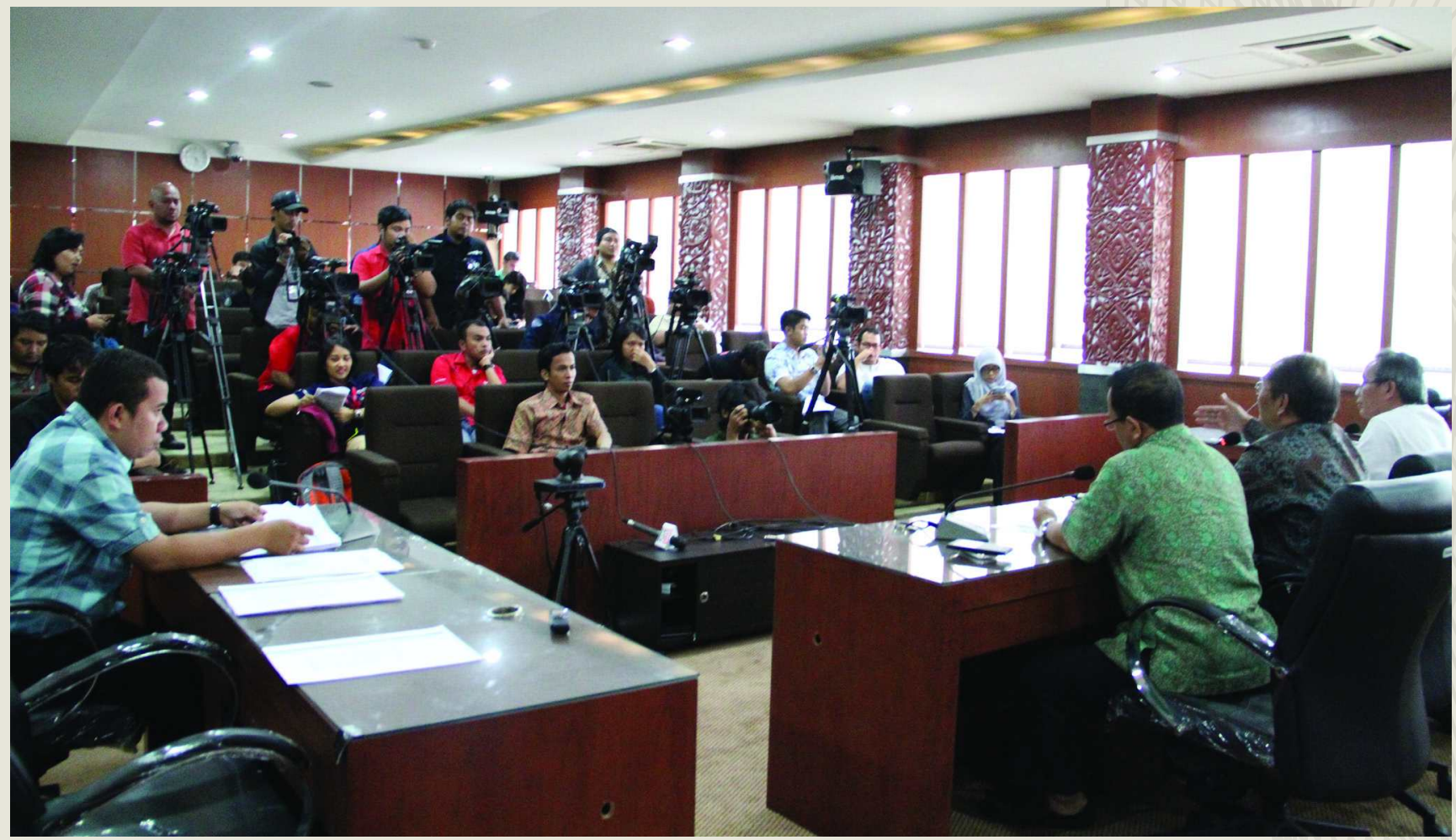

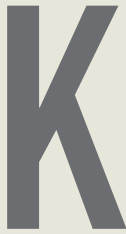

eluarnya putusan Dewan Kehormatan Penyelenggara Pemilu (DKPP) dan putusan Mahkamah Konstitusi (MK) terkait hasil Pilpres 20I4 pada Kamis (2I/8) disikapi secara beragam. Ada yang puas dan ada juga yang tidak puas. Namun, menurut Ketua DKPP Prof Jimly Asshiddiqie, yang pasti putusan itu sudah final dan mengikat.

"Dengan keluarnya putusan MK, kemarin, ini berarti semua proses hukum terkait Pilpres sudah berakhir. Tidak dapat diganggu gugat," demikian tegas Jimly, sehari setelah putusan tersebut, Jumat (22/8).

Penegasan Jimly tersebut disampaikan saat menggelar konferensi pers di kantor DKPP, Jln. MH Thamrin I4, Jakarta. Mantan Ketua MK ini meminta semua pihak untuk menerima hasil yang ada. Kalaupun masih ada persaingan, dia mempersilakan itu dilakukan di front lain.

"Saya berpendapat Pilpres 20I4 ini sukses. Sukses bagi kita semua, baik partai pengusung calon maupun rakyat sebagai pemilih. Be possitive!" tuturnya. Menurut Jimly, Pilpres 2014 menjadi pengalaman paling berharga bagi Indonesia. Untuk pertama kalinya, ada dua pasangan calon yang bertarung dan kemungkinan besar tidak akan terulang pada Pemilu 20I9. Pasalnya, Pemilu 2oI9 digelar secara serentak, sehingga masing-masing partai politik akan mengajukan calonnya sendiri.

"Jadi, munculnya dua pasangan calon ini bisa jadi yang pertama dan terakhir di negeri ini. Dan saya sangat bersyukur, semua diakhiri dengan baik," terang dia.

Karena proses sudah selesai, Jimly berharap pasangan Prabowo-Hatta segera memberi ucapan selamat kepada presiden dan wakil presiden terpilih Jokowi-Jusuf Kalla. Baginya, ucapan selamat itu sesuatu yang serius dan menunjukkan kenegarawanan seseorang.

"Kita sudah punya presiden baru yang bakal dilantik 20 Oktober nanti. Kita harus ucapkan selamat. Dua bulan yang ada ini kita manfaatkan untuk healing process, untuk rekonsiliasi," ujar Jimly. ArifSyarwani 


\section{Menuntaskan Perkara Pilpres}

P

enyelenggaraan Pemilu Presiden dan Wakil Presiden (Pilpres) 2014 tidak luput dari kekurangan. Kinerja para penyelenggara Pemilu, baik jajaran Komisi Pemilihan Umum (KPU) maupun Badan Pengawas Pemilu (Bawaslu) menuai ketidakpuasan dari dua kubu pasangan calon, Prabowo Subianto-Hatta dan Jokowi-Jusuf Kalla. Dewan Kehormatan Penyelenggara Pemilu (DKPP) sebagai penegak kode etik dua institusi penyelenggara Pemilu tersebut pun menjadi sarana pencari keadilan oleh dua kubu.

Ada sebanyak I4 pengaduan/perkara yang masuk ke DKPP terkait penyelenggaraan Pilpres 20I4. Ke-I4 perkara tersebut, Io perkara diadukan oleh Tim Pasangan Calon (Paslon) Nomor I Prabowo-Hatta, dua perkara diadukan oleh Tim Paslon Nomor 2 Jokowi-JK, serta dua perkara lagi diadukan oleh kelompok independen. Terhadap I4 pengaduan, jauh-jauh hari telah dipersiapkan pelaksanaan persidangannya. Ketua DKPP Jimly Asshiddiqie bersama Anggota memutuskan, perkara Pilpres akan menjadi prioritas. Oleh karena itu, sidang harus digelar secara marathon agar segera diberikan putusan.

"Pengaduan ke DKPP memang tidak ada kedaluwarsanya. Tidak kayak di MK (Mahkamah Konstitusi) yang hanya dibatasi $3 \times 24$ jam. Tapi karena persoalan Pilpres ini hal yang serius maka kita prioritaskan. Kita harus segera tuntaskan perkara Pilpres ini. Supaya persoalan ini segera dapat diakhiri dengan salaman. Harus dihormati rakyat yang telah memilih," tutur Jimly.

Dari mana saja asal pengaduan, ternyata tidak hanya diajukan oleh Tim Kampanye Nasional (Tim Kamnas) dua kubu. Ada juga yang diajukan oleh pendukung capres-cawapres dari daerah, seperti dari Kabupaten Banyuwangi, Kota Surabaya, Provinsi Jawa Timur, dan dari Kabupaten Sukoharjo (Jawa Tengah), Dogiyai (Papua), DKI Jakarta, dan Halmahera Timur (Maluku Utara). Satu lagi pengaduan disampaikan oleh perseorangan yang kemudian disebut sebagai kelompok independen, yakni dari Rizaldi Limpaz dan Yusuf DJ (dosen Universitas Jakarta).

DKPP memulai sidang perkara Pilpres pada Jumat (8/8). Mengingat perha- tian masyarakat terhadap perkara ini begitu besar, DKPP memutuskan untuk meminjam Gedung KH M Rasjidi di lingkungan Kementerian Agama RI, Jl MH Thamrin 6, Jakarta. Ruang sidang DKPP yang hanya memiliki kapasitas sekitar 60 orang dipastikan tidak akan mampu menampung pengunjung sidang yang begitu banyak. Dan benar saja, pada sidang pertama, Gedung $\mathrm{KH}$ M Rasjidi, Kemenag RI, yang sebenarnya hanya berkapasitas sekitar 200-an orang dipenuhi sekitar 300 orang, baik dari Pengadu, Teradu, pendukung dua kubu, serta awak media massa.

Pada sidang perdana, Majelis sidang yang dipimpin oleh Prof. Jimly Asshiddiqie didampingi Anggota Nur Hidayat Sardini, Saut Hamonangan Sirait, Anna

Sesuai pasal 9, UU 15
Tahun 2011 tentang
Penyelenggara Pemilu,
KPU diharuskan
menindaklanjuti
rekomendasi Bawaslu
secara segera. KPU
provinsi dan kabupaten/
kota juga wajib
melaksanakan tugas yang
diberikan KPU RI."

Erliyana, dan Valina Singka Subekti meminta agar sidang hanya untuk mengklarifikasi beberapa persoalan, seperti materi pengaduan, subjek hukumnya, serta kejelasan Pengadu dan Teradunya.

"Pilpres ini kan pesertanya cuma dua. Jadi kami minta, kalau pokok persoalannya sama, dan dari Tim yang sama, lebih baik pengaduan digabung saja. Silakan tim melakukan konsolidasi internal, nanti ditentukan siapa yang mewakili," saran Jimly.

Saran dari Ketua Majelis disetujui oleh para Pengadu. Pada sidang kedua, pada Senin (II/8) telah mengerucut menjadi tiga kelompok Pengadu. Masing-masing Pengadu mengajukan perwakilan yang mereka sepakati. Pertama adalah dari Tim Kampanye Pasangan
Calon Nomor I Prabowo-Hatta diwakili oleh Mahendradatta. Kedua, dari Tim Kampanye Pasangan Calon Nomor 2 Jokowi-Jusuf Kalla diwakili Denny Iskandar dan Sandy Ebenezer. Ketiga, dari kelompok independen yang diajukan oleh Rizaldi Limpaz dan Yusuf DJ Hasani (dosen Universitas Jakarta).

Pada sidang kedua ini agendanya sebenarnya mendengar penyampaian pokok-pokok pengaduan oleh Pengadu dan mendengar jawaban Teradu. Akan tetapi, mengingat banyaknya materi pengaduan, maka sidang yang digelar dari pagi sampai malam hari itu hanya memberi kesempatan kepada Pengadu untuk menyampaikan materi pengaduannya. Selain itu, para Teradu seperti disampaikan oleh Ketua KPU Husni Kamil Manik dan Ketua Bawaslu Muhammad juga belum siap memberikan jawaban pada hari itu. Mereka meminta waktu untuk mempelajari pengaduan sekaligus akan menyiapkan jawaban terperinci secara tertulis.

Dari tiga kelompok Pengadu setidaknya ada empat pokok pengaduan yang mengemuka, yakni soal syarat administrasi pencalonan capres-cawapres, soal pembukaan kotak suara, soal daftar pemilih khusus tambahan (DPKTb), dan soal penggunaan kartu tanda penduduk (KTP) bagi pemilih. Soal syarat administrasi capres-cawapres, baik Tim Prabowo-Hatta dan Jokowi-JK samasama mengajukan pengaduan. Tim Prabowo-Hatta menggugat keputusan KPU yang meloloskan Capres Jokowi. Menurut mereka, keputusan itu cacat secara administratif karena Jokowi tidak memenuhi syarat terkait izinnya kepada Presiden.

"Sesuai ketentuan Permendagri Nomor 13 Tahun 2009, calon presiden atau wakil presiden yang masih menjabat sebagai gubernur harus meminta izin kepada presiden paling lambat 7 hari sebelum masa pendaftaran. Berdasarkan data yang dimiliki Pengadu, Jokowi baru meminta izin kepada Presiden Susilo Bambang Yudhoyono pada I3 Mei 2014. Padahal, pendaftaran capres-cawapres dibuka pada I9 Mei 20I4. Ini berarti masa izin Jokowi hanya 6 hari," ujar Mahendradatta.

Namun, dalam sidang ketiga, Rabu (13/8,) di mana KPU diberi kesempatan memberikan jawaban, Ketua 


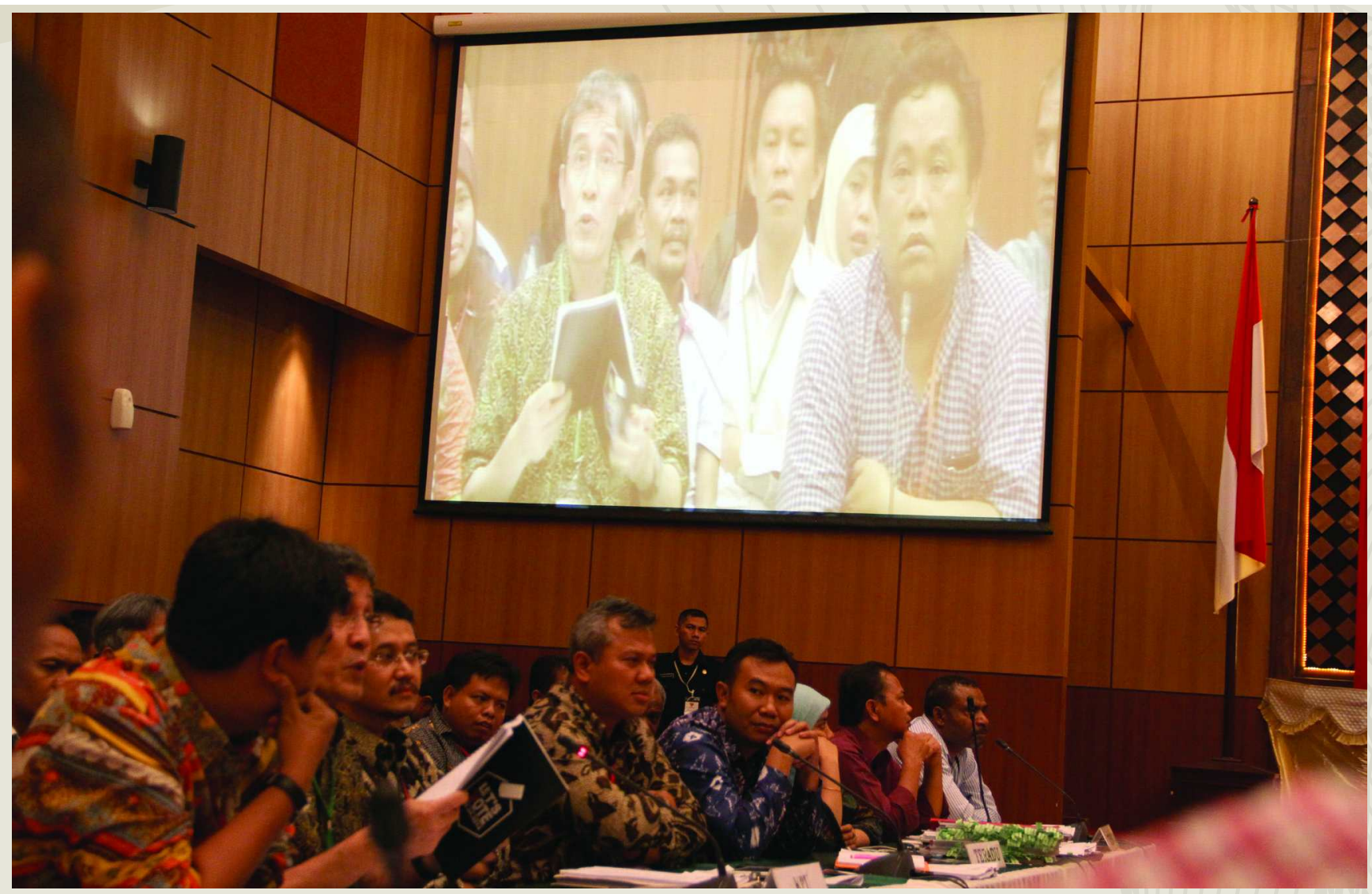

KPU Husni Kamil Manik membantah sangkaan Pengadu. Dalam data yang dimiliki KPU, izin Jokowi kepada presiden telah memenuhi syarat. "Menyangkut batas waktu izin Jokowi seperti tercantum dalam formulir DB 7 telah dilengkapi dengan surat Gubernur Nomor 4I3 tertanggal 8 Mei 2014 perihal izin kepada presiden. Merujuk pada tanggal ini, maka ketentuan ini telah tercapai jika pendaftaran I9 Mei," terang Husni Kamil Manik.

Sedangkan Tim Jokowi-JK seperti dilaporkan Sigop Tambunan menggugat keputusan Bawaslu. Sebelumnya, Sigop melaporkan KPU ke Bawaslu karena keputusannya meloloskan Capres Prabowo. Menurut Sigop, Prabowo seharusnya tidak layak menjadi capres karena cacat administratif. Prabowo dianggap memberikan keterangan palsu terkait daftar riwayat hidupnya sebagai ketua Himpunan Kerukunan Tani Indonesia (HKTI). Namun, Bawaslu berkata lain. Keputusan KPU, menurut Bawaslu, tidak ada pelanggaran Pemilu.

Untuk soal pembukaan kotak suara, perkara ini juga diajukan oleh Tim Prabowo-Hatta. Pembukaan kotak suara terjadi di beberapa TPS di DKI Jakarta. Tim mengadukan Ketua KPU DKI Jakarta Sumarno dan komisioner KPU di 5 kota administrasi Jakarta, yakni KPU Jakarta Pusat, KPU Jakarta Barat, KPU Jakarta Selatan, KPU Jakarta Utara, dan KPU Jakarta Timur. Menurut para Pengadu, pembukaan kotak suara pada 23 Juli 2014 itu tidak ada dasarnya, cacat hukum, dan melanggar kode etik penyelenggara Pemilu.
Pada sidang Rabu (I3/8), Ketua KPU DKI Sumarno menjelaskan dasar hukum pembukaan kotak suara tersebut. Ada dua dasar hukum KPU DKI dan beberapa kota membuka kotak suara. Pertama adalah surat rekomendasi Bawaslu DKI Nomor 276 serta Surat Edaran (SE) KPU RI Nomor I446 dan I449. Dalam rekomendasi Bawaslu DKI Nomor 276, kata Sumarno, memerintahkan KPU DKI untuk melakukan pengecekan terhadap dokumen khususnya di dua kota, yakni di Jakarta Utara dan Jakarta Pusat. Atas rekomendasi itu, KPU DKI diharuskan membuka kotak suara di dua kota tersebut. Sedangkan, SE KPU Nomor I446 dan I449, juga memerintahkan KPU Provinsi membuka kotak suara untuk kepentingan persiapan sengketa perselisihan hasil di Mahkamah Konstitusi (MK).

"Jadi itu dasar kami, Majelis. Sesuai pasal 9, UU I5 Tahun 2ori tentang Penyelenggara Pemilu, KPU diharuskan menindaklanjuti rekomendasi Bawaslu secara segera. KPU provinsi dan kabupaten/kota juga wajib melaksanakan tugas yang diberikan KPU RI," ungkap Sumarno.

Terkait DPKTb, pengaduan diajukan Tim Prabowo-Hatta menyikapi Pilpres di Kota Surabaya, Jawa Timur. Dalam sidang DKPP, Kamis (I4/8), perwakilan Tim Prabowo-Hatta, Didi Supriyanto, memandu tiga saksi yang diajukan untuk menerangkan soal penggunaan DPKTb di Kota Surabaya. Ketiga saksi adalah Soleh, Afif Alfatih, dan Taufik.

Saksi Soleh menerangkan, penggunaan DPKTb di Kota Surabaya tidak sesuai aturan karena dibolehkan hanya menggunakan keterangan domisili. Akhirnya terjadi mobilisasi pemilih di beberapa TPS. Sementara itu, saksi Afif yang mengaku sebagai korban dari keputusan KPU Surabaya tersebut. Dia berdomisili di Surabaya, tapi ber-KTP Bekasi. Mengetahui dibolehkan menggunakan keterangan domisili, dia berniat mencoblos di sebuah rumah sakit.

"Saya mengantre untuk mencoblos di rumah sakit, karena kata teman di situ bisa mencoblos pakai keterangan domisili. Akan tetapi, setelah mengantre lama, saya tidak dapat mencoblos. TPS ditutup pukul I3.0o. Padahal saya lihat masih banyak yang mengantre," beber Afif.

Atas kesaksian Afif, Komisioner KPU Juri Ardiantoro bertanya apakah Afif telah mengurus formulir pindah TPS (A5), apakah tahu siapa saja yang boleh mencoblos di rumah sakit, dan apakah sudah mendaftar ketika mengantre. Jawabannya, semua belum dilakukan oleh Afif. "Kalau belum mengurus A5 dan belum mendaftar memang tidak dibolehkan mencoblos. Untuk diketahui, TPS di rumah sakit diperuntukkan bagi pasien dan karyawan di situ," terang Juri.

Rizaldi Limpas, salah satu Pengadu dalam sidang kode etik DKPP menggugat keputusan Komisi Pemilihan Umum (KPU) yang membolehkan penggunaan Kartu Tanda Penduduk (KTP) dalam Pemilihan Presiden dan Wakil Presiden (Pilpres) 20I4. Menurutnya, keputusan itu telah melanggar kode etik penyelenggara Pemilu, khususnya terkait asas 


\section{Kupas Tuntas}

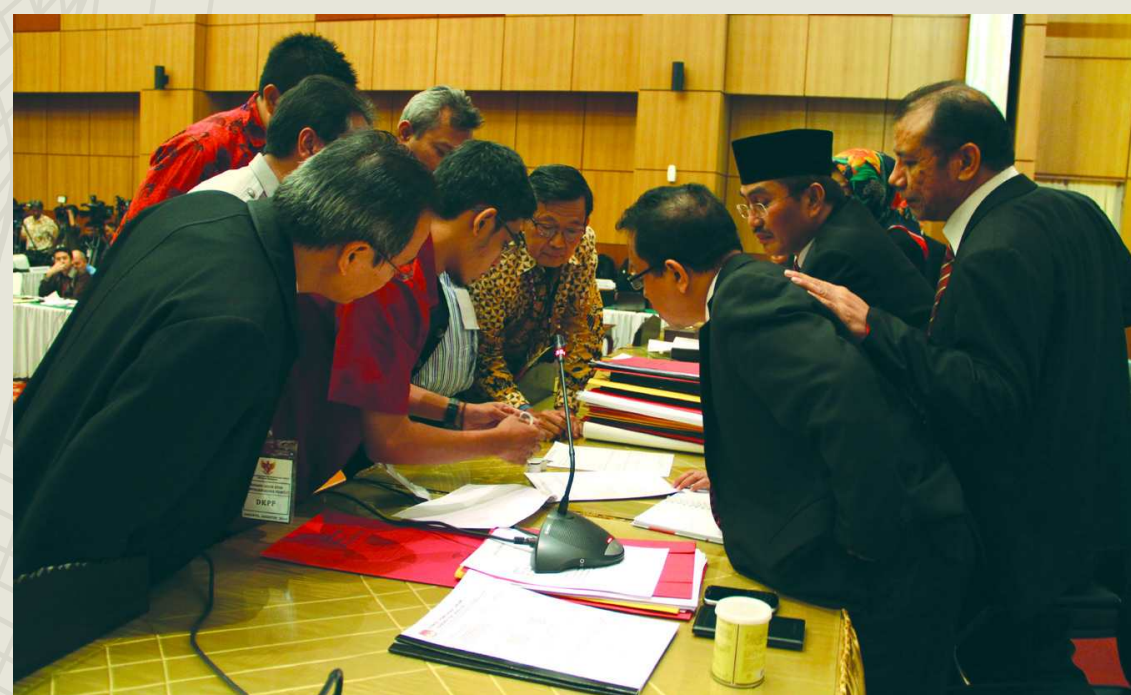

kepastian hukum.

"Meskipun keputusan itu didasarkan pada putusan Mahkamah Konstitusi (MK), tapi itu tidak dapat digeneralisir. Putusan MK tersebut harus dipahami sifatnya kasuistik, yakni untuk penyelenggaraan Pilpres 2009," beber Rizaldi dalam sidang kedua, Senin (II/8).

Sidang kode etik perkara Pilpres oleh DKPP ini digelar berbarengan dengan sidang perselisihan hasil Pemilu (PHPU) di Mahkamah Konstitusi (MK). Para pihak, baik Pengadu, Teradu, Saksi, dan Ahli harus mengatur waktu untuk bergiliran hadir antara di DKPP dan MK. Untuk sidang DKPP digelar lima kali, mulai dari 8, II, I3, I4, dan I5 Agustus
20I4. Di sidang kelima, Pengadu dan Teradu menghadirkan Ahli. Di antara Ahli yang dihadirkan Tim PrabowoHatta adalah Margaritno Kamis (pakar hukum tata negara) dan Said Salahuddin (Direktur Sinergi Masyarakat untuk Demokrasi Indonesia/Sigma). Sedangkan Tim Jokowi-JK menghadirkan Haryono (mantan hakim konstitusi MK).

Lima kali sidang yang digelar DKPP dapat dikatakan sebagai sidang pemeriksaan. Selanjutnya tinggal sidang putusan. DKPP memutuskan menggunakan waktu selama enam hari untuk rapat pleno dan menyusun naskah putusan. Pada Kamis (2I/8) dengan tem- pat yang sama di Gedung Kementerian Agama, putusan dibacakan. Di hari yang sama, MK juga membacakan putusannya. Hanya saja, DKPP mengambil waktu pagi, sementara MK sore hari. Hasil putusan menyatakan tiga hal, yakni pemberhentian tetap, peringatan, dan rehabilitasi. Lima komisioner KPU Dogiyai dan dua Teradu dari Panwaslu Banyuwangi diberhentikan tetap.

Selain dua daerah tersebut, DKPP menjatuhkan sanksi peringatan dan merehabilitasi nama baik Teradu yang tidak terbukti melanggar kode etik. Tujuh komisioner KPU mendapat dua putusan dalam perkara berbeda, yakni diperingatkan dan direhabilitasi. Sementara itu, Ketua dan Anggota Bawaslu semuanya mendapat rehabilitasi. Dari beberapa putusan DKPP, dua putusan yakni putusan Dogiyai dan Halmahera Timur, memunculkan pendapat berbeda (dissenting opinion) dari Anggota DKPP Nur Hidayat Sardini. Nur Hidayat Sardini menilai, untuk kedua kasus yang terjadi di dua kabupaten itu seharusnya juga menjadi tanggung jawab KPU di tingkatan atasnya, yakni KPU provinsi dan KPU RI. Ini berarti sanksinya pun harus sama. Namun, perbedaan pendapat bukanlah putusan yang mengikat. Dalam putusan DKPP, yang resmi berlaku dan mengikat secara hukum adalah putusan yang dibacakan. ArifSyarwani

\section{Dua Penyelenggara Pemilu Diapresiasi}

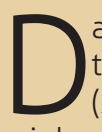

alam sidang pembacaan putusan yang digelar pada Kamis, (21/8) DKPP juga mengapresiasi dua penyelenggara Pemilu yakni, Hadar Nafis Gumay anggota KPU RI dan Subakti Ketua Panwaslu Kabupaten Sukoharjo, keduanya diapresiasi atas kinerja baik serta dedikasinya sebagai penyelenggara Pemilu.

DKPP memberi apresiasi atas sikap etis Hadar Nafis Gumay yang tidak melakukan tindakan hukum atau bentuk lain, untuk membalas fitnah yang dilakukan Pengadu dan narasumber informasi yang dijadikan sebagai saksi dalam perkara yang diajukan oleh Ir. Tonin Tachta Singaribun dan Egi Sudjana. Menurut DKPP, hal ini menunjukkan dedikasi, integritas, dan sikap kenegarawanan yang ditunjukkan oleh Hadar Nafis Gumay. Sebelumnya, Pengadu Ir. Tonin Tachta Singaribun dan Egi Sudjana mempersoalkan terkait pertemuan antara
Hadar Nafis Gumay bersama politisi PDI P Trimedya Pandjaitan. Terhadap pemberitaan negatif diberbagai media massa terkait hal tersebut, Hadar merasa dirinya sangat terhina dan menurutnya, hal ini merupakan pembunuhan karakter terhadap dirinya.

Selanjutnya, DKPP mengapresiasi Subakti karena dalam menjalankan tugasnya dia telah menempuh dan memenuhi persyaratan yang ditentukan peraturan dan melakukan tindakan yang dapat dikategorikan "melampaui kewajiban", sesuatu yang menjadi persyaratan utama untuk menyatakan terima kasih dan penghargaan kepada setiap apparatus negara dan setiap manusia.

Sebelumnya, Subakti dilaporkan oleh Wawan Pribadi karena dianggap telah mengeluarkan rekomendasi lisan saat Pleno Rekapitulasi Pilpres di tingkat Kabupaten mengenai Pemungutan Suara Ulang di TPS 01
Desa Dukuh Kecamatan Mojolaban Kabupaten Sukoharjo. Pengadu mendalilkan bahwa rekomendasi pemungutan suara ulang yang dikeluarkan Panwaslu Kabupaten hanya berdasarkan video youtube.

Berdasarkan fakta di persidangan terungkap fakta adanya temuan dan inisiatif Subakti untuk mendalami dan membuktikan kebenaran secara faktual demi menjamin dan memastikan kualitas Pemilu yang baik. Teradu merespon cepat dan proaktif dengan berusaha untuk mencari informasi lebih lanjut setelah melihat tayangan video youtube.

Atas tindakan Subakti tersebut DKPP menilai bahwa tidakan itu sangatlah terpuji, bertanggungjawab dan profesional karena telah berupaya proaktif untuk melakukan pengawasan pelaksanaan tahapan Pilpres sesuai tugasnya sebagai anggota Panwaslu. 


\section{Kolom Anggota}

\section{Satu Anggota Majelis Berbeda Pendapat}

A

da suasana baru di DKPP.

Majelis hakim memberikan ruang keterbukaan ke-

pada anggotanya saat terjadi perbedaan pendapat terkait

Putusan. Namanya pun dican-

tumkan. Sebelumnya, dissenting opinion disampaikan namun tidak disebutkan hakim yang berbeda pendapat itu. Seperti pada Putusan Kode Etik KPU Halmahera Timur dan KPU Dogiyai terkait Pemilihan Presiden 2014.

"DKPP menjatuhkan sanksi berupa peringatan keras kepada Rustam Adam, Mamat Jalil, Ade Kamaludin, Asbur Somadayo, Nur Syamsi selaku ketua dan anggota KPU Kabupaten Halmahera Timur," kata Saut H Sirait saat membacakan Putusan, Kamis (2I/8). Selaku ketua majelis Jimly Asshiddiqie dan anggota majelis Nur Hidayat Sardini, Anna Erliyana dan Valina Singka Subekti.

Yang menjadi pertimbangan majelis, Teradu terlalu terburu-buru melaksanakan pemungutan suara ulang (PSU). Berdasarkan ketentuan, batas akhir pelaksanaan PSU ig Juli 20I4 dan keputusan untuk melaksanakan pada I5 Juli merupakan langkah yang mengakibatkan kurangnya persiapan, koordinasi dan sosialisasi kepada seluruh masyarakat. Selain itu, pemberhentian kepada ketua dan anggota KPPS mendekati pelaksanaan PSU menunjukan sikap para Teradu yang tidak memiliki perencanaan dan perhitungan yang baik. Teradu dinilai melanggar asas profesionalitas.

Untuk diketahui, Panwaslu Haltim mengadukan para Teradu, ketua dan anggota KPU Haltim karena dinilai tidak melaksanakan rekomendasinya, untuk melaksanakan pemungutan suara ulang di TPS I dan TPS 2 Desa Soasangaji serta TPS I Desa Tewil Kecamatan Kota Maba Kabupaten Haltim. Rekomendasi itu keluar karena ada pelanggara berupa penggunaan hak pilih lebih dari satu kali pada pemungutan suara 9 Juli 2014 lalu. Ternyata KPU Haltim gagal melakukan PS di dua TPS yakni TPS I dan TPS 2 Desa Soasangaji.

Sementara anggota majelis lain, Nur Hidayat Sardini berpendapat, penjatuhan sanksi dalam Putusan berupa Peringatan Keras kepada para Teradu yakni seharusnya berupa Pemberhentian Tetap, karena apa yang dilakukan oleh para Teradu melanggar prinsip-prinsip Pemilu sebagai wujud

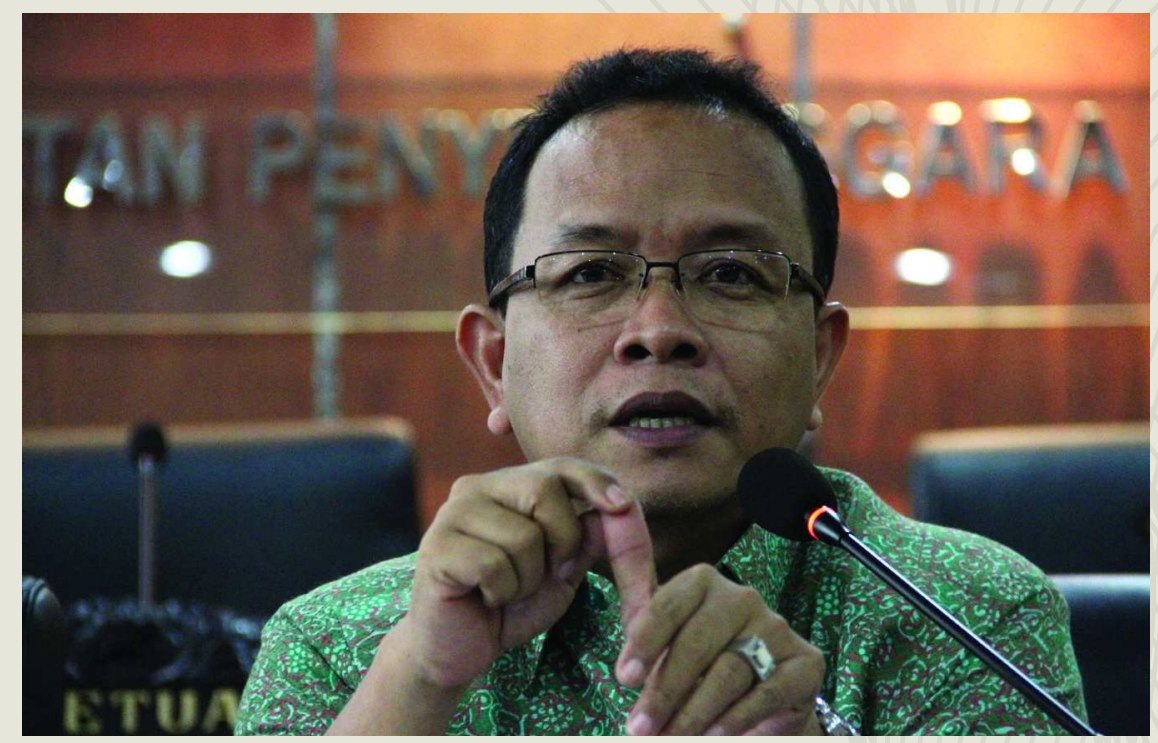

kedaulatan rakyat.

Dia menjelaskan bahwa apa yang terjadi dalam pelaksanaan Pemilu di Halmahera Timur, Maluku Utara, tepatnya di TPS I dan TPS 2 Desa Soasangaji Kecamatan Kota Maba, adalah bentuk pelanggaran hak-hak asasi manusia tersebut. Pasalnya, sebanyak I.oI3 (547+466) jiwa, akhirnya tidak dapat menggunakan hak memilihnya, karena langkah yang dilakukan oleh Teradu yakni Ketua dan anggota KPU Halmahera Timur, tidak memungkinkan menggelar Pemungutan dan Penghitungan Suara dalam Pemungutan Suara Ulang (PSU), dalam Pemilu Presiden dan Wakil Presiden Tahun 20I4, sebagaimana rekomendasi Panwaslu Halmahera Timur No. 50/ Panwaslu-HT/VII/20I4 tanggal I4 Juli 20I4. Sementara hari Pemungutan dan Penghitungan Suara pada I5 Juli 20I4 tidak ada seorang pun pemilih menghadiri dan menggunakan hak memilihnya di TPS setempat, sehingga oleh KPPS setempat menyatakan "masing-masing Paslon tidak memeroleh suara”.

Terhadap Putusan KPU Dogiyai, DKPP menjatuhkan sanksi berupa Pemberhentian Tetap kepada Didimus Dogomo, Yohanes lyai, Ev Emanual Keiya, Yulianus Agapa dan Palfianus Kegou, selaku ketua dan anggota KPU Kabupaten.

Majelis berpendapat sesuai temuan dan kajian Bawaslu Provinsi Papua yang didasarkan pada laporan dan rekomendasi Panwaslu Kabupaten Dogiyai, para Teradu selaku ketua dan anggota KPU Dogiyai telah sengaja meniadakan pemilihan di dua distrik, yakni Distrik Mapia Tengah dan Distrik Mapia Barat. Hal tersebut terjadi bukan akibat bencana alam, kerusuhan atau kondisi-kondisi khusus lainnya yang dimungkinkan oleh ketentuan peraturan perundang-undangan melainkan disebabkan persoalan yang sepenuhnya berada pada diri para Teradu dan hanya diketahui oleh para Teradu sendiri.

Nur Hidayat Sardini menilai, pelaksanaan Pemilu Presiden dan Wakil Presiden Tahun 20I4, di Distrik Mapia Tengah dan Mapia Barat Dogiyai Papua, telah terjadi kegagalan dalam mendistribusikan logistik Pemilu atau tidak tepat sasaran dan tepat waktu, sehingga pemungutan dan penghitungan suara (voting day) Pemilu gagal dilakukan, berakibat hilangnya kesempatan, atau sekurang-kurangnya terganggunya penggunaan hak memilih (rights to vote)-nya terhadap I8.022 pemilih di kedua distrik tersebut. Teradu Ketua dan anggota KPU Dogiyai dikenakan sanksi berupa "Pemberhentian Tetap".

"Patut kiranya apabila tidak hanya KPU setempat yang diganjar dengan sanksi Pemberhentian Tetap, namun otoritas Pemilu di jenjang atasnya, tak terkecuali KPU RI, sebagai penanggung jawab utama (leading sector) Pemilu, layak untuk dimintai pertanggungjawaban terhadap gagalnya perwujudan Pemilu sebagaimana prinsip Pemilu berkedaulatan rakyat. Oleh karena harus disadari bahwa, pengoreksian (corrective) terhadap proses Pemilu dapat dimungkinkan dengan mengacu Bab XV UU No. 42 Tahun 2008," katanya. Teten Jamaludin 


\section{Ragam}

\section{Menyaksikan Sidang, Pengunjung Rela Lesehan}

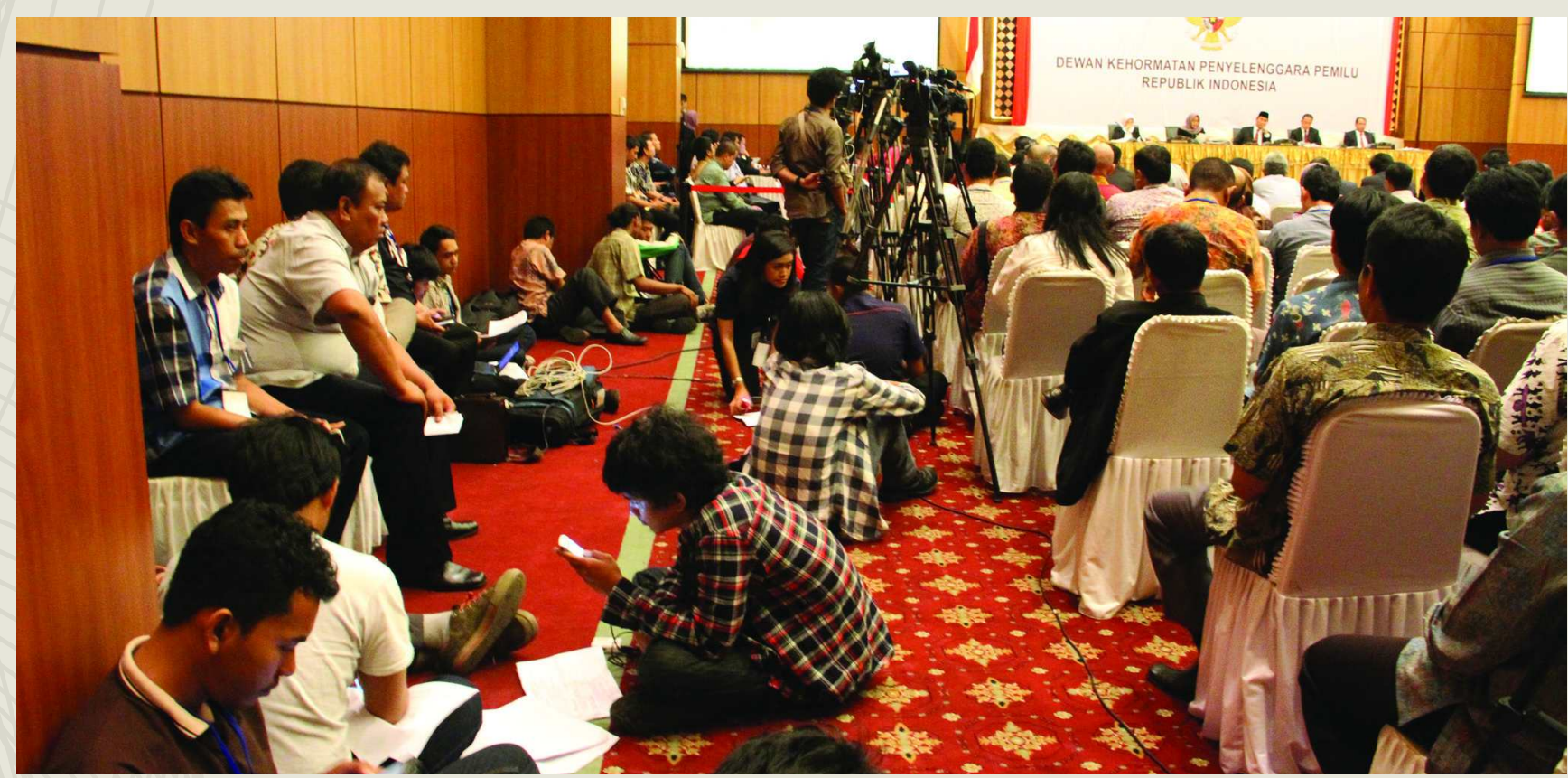

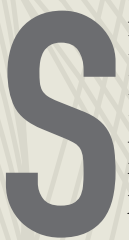

idang kode etik KPU dan Bawaslu terkait Pemilihan Presiden menyita perhatian publik baik di sidang pertama hingga sidang terakhir. Sidang bertempat di Ruang KH M Rasjidi, Kantor Kementerian Agama, Jalan MH Thamrin No.6 Jakarta. Ruang sidang penuh. Mereka yang hadir baik dari pihak-pihak yang berkepentingan dan para awak media.

Pengunjung yang tidak kebagian tempat duduk, mereka duduk lesehan di ruang lobi. Mereka menyaksikan melalui layar kaca yang dipasang oleh panitia sidang.

Sementara di luar sidang, selalu ada saja organisasi massa yang berdemonstrasi baik dari sidang pertama hingga sidang kelima, pembacaan Putusan. Mereka menuntut agar hakim DKPP menegakkan keadilan dan kebenaran. Mereka pun menutut agar penegak hukum tidak mudah diintervensi oleh para pihak asing.

Sidang ini memang terbuka untuk umum. Meski demikian, hanya pengunjung yang memiliki ID card yang dibolehkan masuk ke ruang sidang. Hal ini guna menjaga kekhidmatan dan keamanan dalam proses persidangan.

Meskipun begitu ada saja pengunjung yang tidak memiliki ID card yang ingin masuk persidangan. Seperti Yakob, salah seorang demontrans, yang

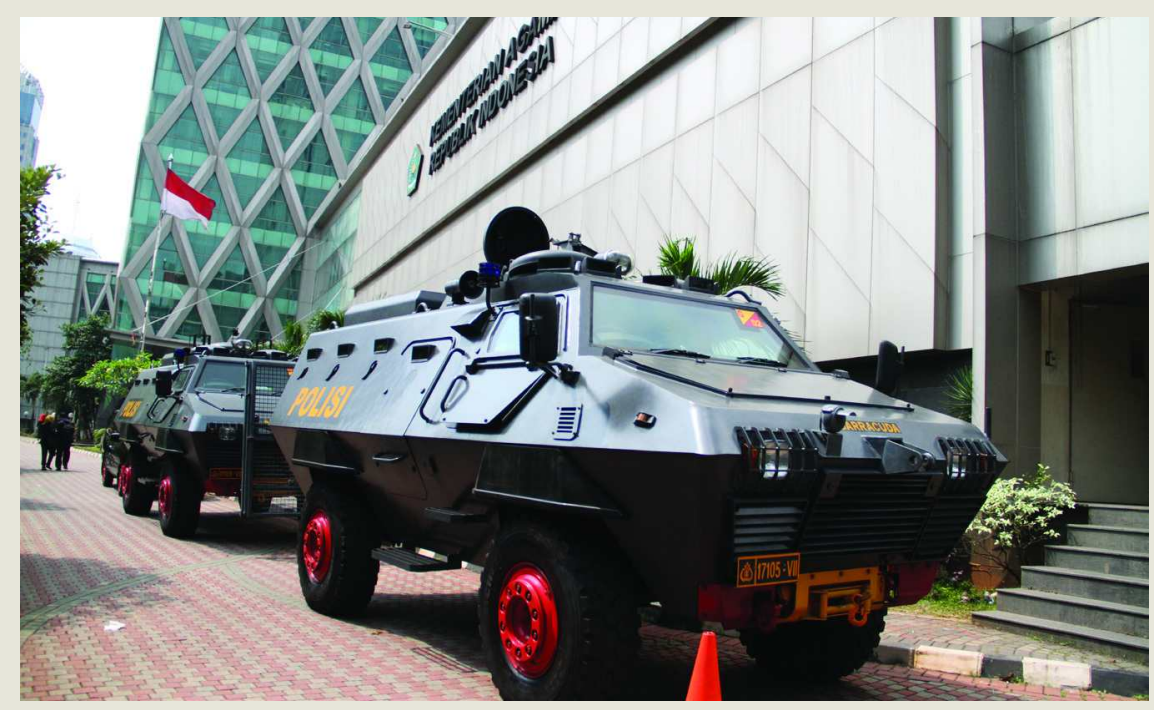

memaksa masuk ke ruang sidang DKPP. Aksi tersebut bisa dicegah oleh petugas keamanan.

Yakob ingin masuk ke ruang persidangan untuk menyerahkan bukti foto kepada panel majelis sidang. Foto yang diserahkan terkait gambar salah satu capres yang sedang foto bersama mantan hakim Mahkamah Konstitusi. Guna menjaga keamanan, dia tidak diperkenankan oleh petugas keamanan masuk. Foto itu cukup diserahkan kepada kuasa hukum pasangan PrabowoHatta.

Jalannya persidangan dijaga ketat. Pengamanan dilakukan baik secara berlapis baik terbuka maupun tertutup.
Menurut AKBP Gunawan, kapolsek Menteng, pihaknya menerjunkan sebanyak 700 personel gabungan. Mereka dari Ditlantas Polda Metro Jaya, Serse Kriminal Umum Polda Metro Jaya, Pam Operasi Vital Metro Jaya, Bimmas Polda Metro Jaya, dan Polsek Menteng. "Dua armada barakuda pun standbye," katanya.

Selama lima kali persidangan dari hari pertama, Jumat ( $15 / 8)$ hingga pembacaan Putusan, Jumat (22/8) sidang berjalan lancar dan aman. Pembacaan putusan jadwalnya dibarengkan dengan pembacaan Putusan gugatan tim Prabowo-Hatta di Mahkamah Konstitusi. . 


\section{Aneka Barang-Barang Pengunjung Sidang Pilpres}

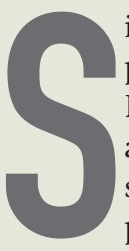

idang kode etik dugaan pelanggaran kode etik KPU RI dan Bawaslu RI mendapat antusias dari pengunjung sidang. Dari mulai awal persidangan hingga akhir, jumlah pengunjung yang tidak sedikit. Mereka yang hadir baik dari masyarakat maupun dari pihak yang berkepentingan, para Pengadu.

Meski sidang hingga malam, pengungjung masih antusias mengikuti jalannya persidangan. Setiap pengunjung yang datang, tidak sedikit yang membawa barang-barang bawaan. $\mathrm{Na}$ mun ada barang-barang yang terpaksa diamankan terlebih dahulu.

Seperti pantauan Humas DKPP, ada barang-barang yang terpaksa diamankan oleh Pamdal sidang. Barangbarang tersebut seperti parfum, air mineral, gunting, korek api, mainan listrik dan lain-lain.

Menurut koordinator Pengamanan Dalam Taslim, barang-barang tersebut terpaksa diamankan sementara. Hal ini sebagai langkah antisipatif demi kelancaran sidang. "Barang-barang tersebut dipersilakan diambil lagi setelah sidang selesai," katanya.

Di lain waktu, Petugas Dalam (Pamdal) mengamankan barang bukti yang mencurigakan dari salah seorang pengunjung sidang. Yaitu sebuah benda yang dibungkus rapi dengan lakban.

Pamdal itu pun menyerahkan kepada pihak petugas kepolisian. Saat dibuka oleh petugas, ditemukan beberapa lembar kertas yang penuh dengan tulisan arab. Kertas tersebut membungkus lipatan kulit binatang yang sudah kering. Panjang kulit tersebut sekitar $40 \mathrm{~cm}$ dan lebarnya I, $5 \mathrm{~cm}$. Pada bagian belakang kulit tulisan berhuruf Arab. Benda tersebut kembali diserahkan kepada petugas pamdal karena bukan barang yang dianggap membahayakan.

Menurut Mutia Purba, petugas pengamanan dalam (pamdal) sidang, ada salah seorang pengunjung sidang yang masuk membawa tas. Kemudian dia memeriksa isi dalam tas itu. "Saya angkat ada dua parfum. Tapi saya lihat lagi di bawah parfum itu ada barang yang dibungkus rapi dengan lakban,
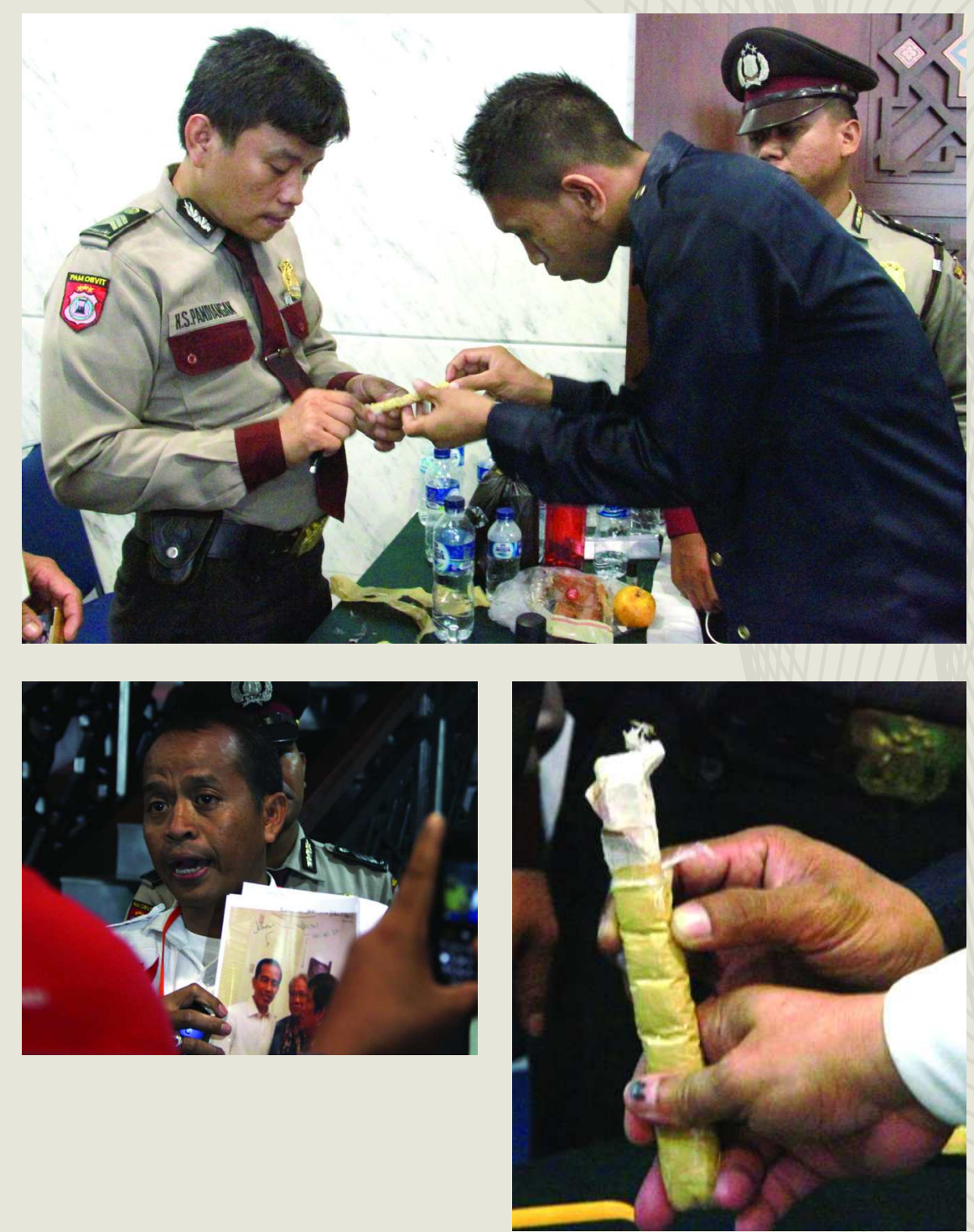

Seperti pantauan Humas DKPP, ada barang-barang yang terpaksa diamankan oleh Pamdal sidang. Barang-barang tersebut seperti parfum, air mineral, gunting, korek api, mainan listrik dan lain-lain. kata pria yang bertugas memeriksa isi tas seluruh pengunjung sidang," katanya.

Kemudian, dia curiga barang tersebut itu narkoba. Dia pun melapor ke polisi dan menyerahkan barang yang mencurigakan tersebut ke polisi. Petugas kepolisian pun membuka isi bungkusan itu. Saya menduga jimat ini. Ada huruf Arabnya, kulit harimau, kata Purba, sapaan akrabnya.

Lanjut dia, setelah pengunjung itu tahu ada barang yang dianggap mencurigakan, pengunjung itu menyerahkan sepenuhnya kepada petugas akan nasib barangnya itu. "Terserah katanya mau diapain aja," tutup pria dari Medan itu. .

Teten Jamaludin 


\title{
Problematik Pemeriksaan Pelanggaran Kode Etik Penyelenggara Pemilihan Umum \\ (Suatu Tinjauan tentang Ketidakhadiran Saksi dalam Pemeriksaan Pelanggaran Kode Etik Pemilihan Umum di Daerah)
}

\author{
Oleh Dr. Tengku Erwinsyahbana, S.H., M.Hum
}

[Bagian Terakhir Dari Tiga Tulisan]

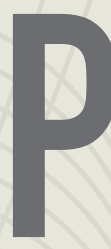

erlu pula dipahami bahwa antara sanksi pelanggaran hukum dengan sanksi pelanggaran etika adalah berbeda, karena menurut American Speech Language Hearing Assocation (ASHA) sebagaimana dikutip Jimly Asshiddiqie, bahwa dalam sistem sanksi etika, bentuk sanksi yang dapat diterapkan adalah:

\section{Reprimand atau teguran;}

Cencure atau pernyataan atau mosi tidak percaya yang dinyatakan secara terbuka dan dipublikasikan di media asosiasi untuk diketahui oleh sesama anggota dan masyarakat luas;

- Revocation atau pencabutan status keanggotaan untuk waktu tertentu, yaitu selama 5 (lima) tahun atau dapat pula dijatuhkan untuk seumur hidup (sampai meninggal dunia);

- Suspension atau penangguhan keanggotaan untuk sementara waktu;

- Withholding atau sanksi penangguhan proses registrasi keanggotaan; dan

- Cease and desist orders atau sebagai tambahan bentuk sanksi lain.

Sehubungan dengan bentuk sanksi yang disebutkan di atas, Jimly Asshiddiqie juga mengatakan bahwa fungsi sanksi etika lebih bersifat pencegahan, selain juga penindakan. Sanksi etika biasanya ditentukan berupa teguran atau peringatan yang bertingkat, mulai dari teguran lisan, teguran tertulis atau teguran ringan dan teguran keras.

Bahkan kadang-kadang ditentukan pula bahwa teguran itu dapat dijatuhkan secara bertahap atau bertingkat, misalnya teguran pertama, teguran kedua dan teguran tingkat terakhir. Bentuk sanksi yang paling keras karena tingkat keseriusan atau beratnya pelanggaran etik yang dilakukan oleh

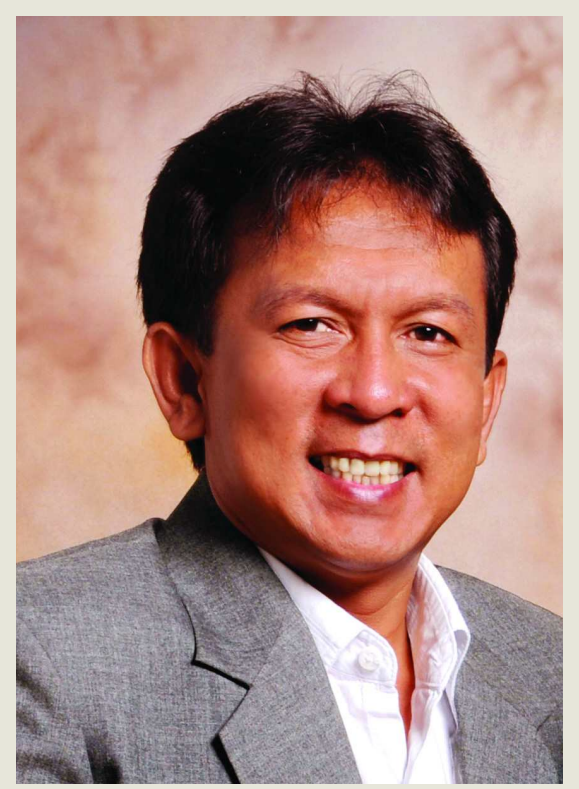

Pelanggaran kode etik penyelenggara pemilihan umum tidak sama dengan pelanggaran hukum, sehingga ketentuan yang terdapat dalam KUHP dan KUHAP yang terkait pemberian sanksi bagi saksi yang tidak mau hadir dalam persidangan tidak dapat diterapkan. seorang aparat atau pemegang jabatan publik (ambts-dragger), adalah sanksi pemberhentian atau pemecatan seseorang dari jabatan publik yang bersangkutan.

Mengingat bentuk sanksi yang dapat dijatuhkan kepada pelaku pelanggaran etik sebagaimana tersebut di atas, maka akan menjadi tidak adil jika seorang saksi yang tidak dapat atau tidak mau hadir dalam pemeriksaan pelanggaran kode etik penyelenggara pemilihan umum dijatuhi hukum (sanksi pidana) berdasarkan Pasal 224 KUHP, Pasal 522 KUHP dan Pasal 159 ayat (2) KUHAP, sedangkan pelaku pelanggaran kode etiknya hanya dapat dijatuhi sanksi etik.

Sebaliknya akan menimbulkan ketidakpastian hukum pula jika kewenangan DKPP dan/atau TPD untuk memanggil dan memeriksa saksi dalam pelanggaran kode etik penyelenggara pemilihan umum, apabila tidak ada upaya paksa berupa sanksi bagi saksi yang tidak mau hadir tersebut, dengan kata lain bahwa hal ini dapat menghi-langkan atau mengurangi wibawa DKPP dan/atau TPD, khususnya untuk memaksa saksi tersebut hadir dalam persidangan, karena urgensi kehadirannya.

\section{Rekomendasi}

Pelanggaran kode etik penyelenggara pemilihan umum tidak sama dengan pelanggaran hukum, sehingga ketentuan yang terdapat dalam KUHP dan KUHAP yang terkait pemberian sanksi bagi saksi yang tidak mau hadir dalam persidangan tidak dapat diterapkan.

Sehubungan hal ini, ketentuan tentang pemberian sanksi bagi saksi yang tidak mau hadir dalam pemeriksaan pelanggaran kode etik penyelenggara pemilihan umum perlu diatur lebih lanjut dalam bentuk undang-undang, yang bertujuan untuk mewujudkan keadilan dan kepastian hukum, sekaligus menjaga wibawa DKPP dan TPD dalam pemeriksaan pelanggaran kode etik penyelenggara pemilihan umum. 


\section{DKPP Kanalisasi Kekecewaan Masyarakat Terhadap Pelanggaran Kode Etik Penyelenggara Pemilu}

P

ascapenyelenggaraan Pemilu Legislatif (Pileg) 9 April lalu, Dewan Kehormatan Penyelenggara Pemilu (DKPP) kebanjiran pengaduan terkait dugaan pelanggaran kode etik penyelenggara pemilu. Ternyata sanksi Pemberhentian Tetap alias "pemecatan" yang diberikan kepada penyelenggara pemilu saat pelaksanaan Pemilu Kepala Daerah (Pilkada) dan pasca Pileg tidak membuat jera. Setidaknya, pada pasca Pileg hingga 30 Juni 20I4, DKPP telah menerima sebanyak 654 pengaduan. Dari 654 pengaduan tersebut perkara yang disidangkan berjumlah 178 perkara. Bahkan sebanyak 85 penyelenggara pemilu dijatuhi sanksi pemecatan. Penyelenggara pemilu yang diberi sanksi terdiri atas jajaran Komisi Pemilihan Umum (KPU) dan Badan Pengawas Pemilu (Bawaslu mulai tingkat kelurahan, kecamatan, kabupaten/kota, dan provinsi. Penyelenggaraan pemilu legislatif masih menyisakan raport merah terhadap integritas penyelenggaraan pemilu. Lantas, bagaimana dengan prediksi penyelenggaraan pemilu presiden dan wakil presiden yang dilaksanakan pada 9 Juli 20I4?

Ketika Pengadu memasukkan laporan kepada DKPP, mereka mengingatkan bahwa suara rakyat adalah suara Tuhan. Hal tersebut harus dihargai. Pengaduan yang membanjir memperlihatkan DKPP bisa menjadi kanal kekecewaan masyarakat. Jika mereka yang kecewa atas penyelenggara Pemilu itu menggunakan cara kekerasan, negara ini bisa kacau. Ketika orang merasa dirugikan, pilihannya memang bisa yang bersangkutan melampiaskan kekecewaan dan kemarahannya dengan jalan kekerasan. Pilihan yang kedua, mereka yang dirugikan melapor kepada pihak berwenang. Saat ini, sudah bukan waktunya menggunakan kekerasan. Jalan kekerasan sudah harus ditinggalkan. Yang terlihat saat ini, perkembangan masyarakat begitu luarbiasa. Informasi dapat disebarluaskan begitu cepat, masyarakat begitu aktif di media sosial. Jika lembaga ini tidak bisa mengimbangi dinamika masyarakat, kondisinya tentu

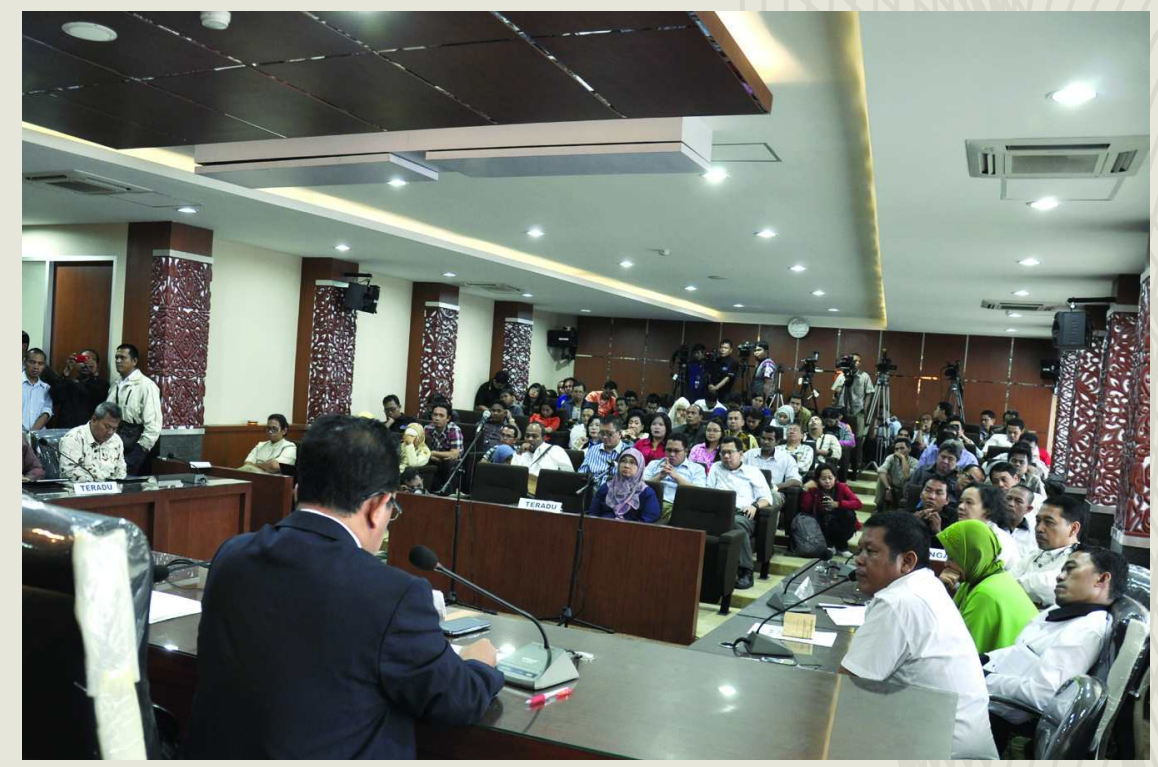

akan semakin kacau. Harus diingat bahwa lembaga negara dibentuk untuk menyelesaikan masalah masyarakat, bukan hanya sekadar ornamen.

Terkait dengan jumlah pelanggaran kode etik yang cenderung tidak menurun, mereka, para penyelenggara Pemilu benar takut kepada DKPP. Akan tetapi karena takut bukan berangkat dari kesadaran, ada saja yang mencoba "kucing-kucingan". Mereka tahu kalau ada hal yang tidak boleh dilakukan. Ini terutama karena orang ingin menggunakan kesempatan Pemilu untuk mengeruk materi. Peristiwa demokrasi menjadi peristiwa ekonomi. Ini terlihat dari sejumlah kasus yang dilaporkan masih seputar soal manipulasi suara, deviasi di PPS atau PPK dan juga KPU daerah. Pada intinya adalah seputar penghilangan suara. Sementara terkait dengan jajaran Bawaslu, mayoritas menyoal mereka yang dianggap tidak menindaklanjuti laporan. Polanya secara umum seperti itu. Masalah tersebut signifikan dan banyak orang yang dirugikan atau terjegal karena itu.

Jelang pemilu presiden DKPP hanya bisa menyerukan agar penyelenggara pemilu bekerja sebaik-baiknya sesuai dengan ketentuan. DKPP jelas akan mengambil tindakan keras untuk setiap dugaan pelanggaran, terutama yang menyangkut permainan suara. Tinggal sekarang persoalan teknis tergantung penyelenggara pemilu. Misalnya saja, jangan sampai logistik terlambat diterima dan salah kirim seperti terjadi saat pemilu legislatif lalu. Apalagi sekarang pemilu presiden hanya ada dua pasangan calon.

Untuk mengantisipasi hal itu DKPP telah menempuh langkah konkret yaitu mengadakan pertemuan tripartit secara rutin. Ada kalanya pertemuannya setiap sebulan sekali. Dalam pertemuan ini terkait tukar informasi proses tahapan pemilu. Dalam pertemuan tripartit dengan KPU dan Bawaslu, hal itu dibahas secara menyeluruh. Peraturan perundang-undangan sebenarnya memungkinkan tindakan pencegahan; KPU dan Bawaslu bisa melakukan pemberhentian sementara (terhadap jajaran penyelenggara pemilu di bawahnya). Bawaslu bisa melakukan tindakan ke dalam jajarannya sendiri dan juga merekomendasikan tindakan (pemberhentian sementara) yang harus diambil KPU kepada jajaran di bawahnya. Ini yang paling dekat yang bisa dilakukan; bisa berupa pemberhentian sementara atau peringatan keras. Hal itu harus dilakukan supaya residu (persoalan) tidak naik ke atas karena persoalan telah diselesaikan di tingkat bawah..

Diah Widyawati 


\section{Ketok Palu}

\section{KPU Disanksi, KPU Dipuji}

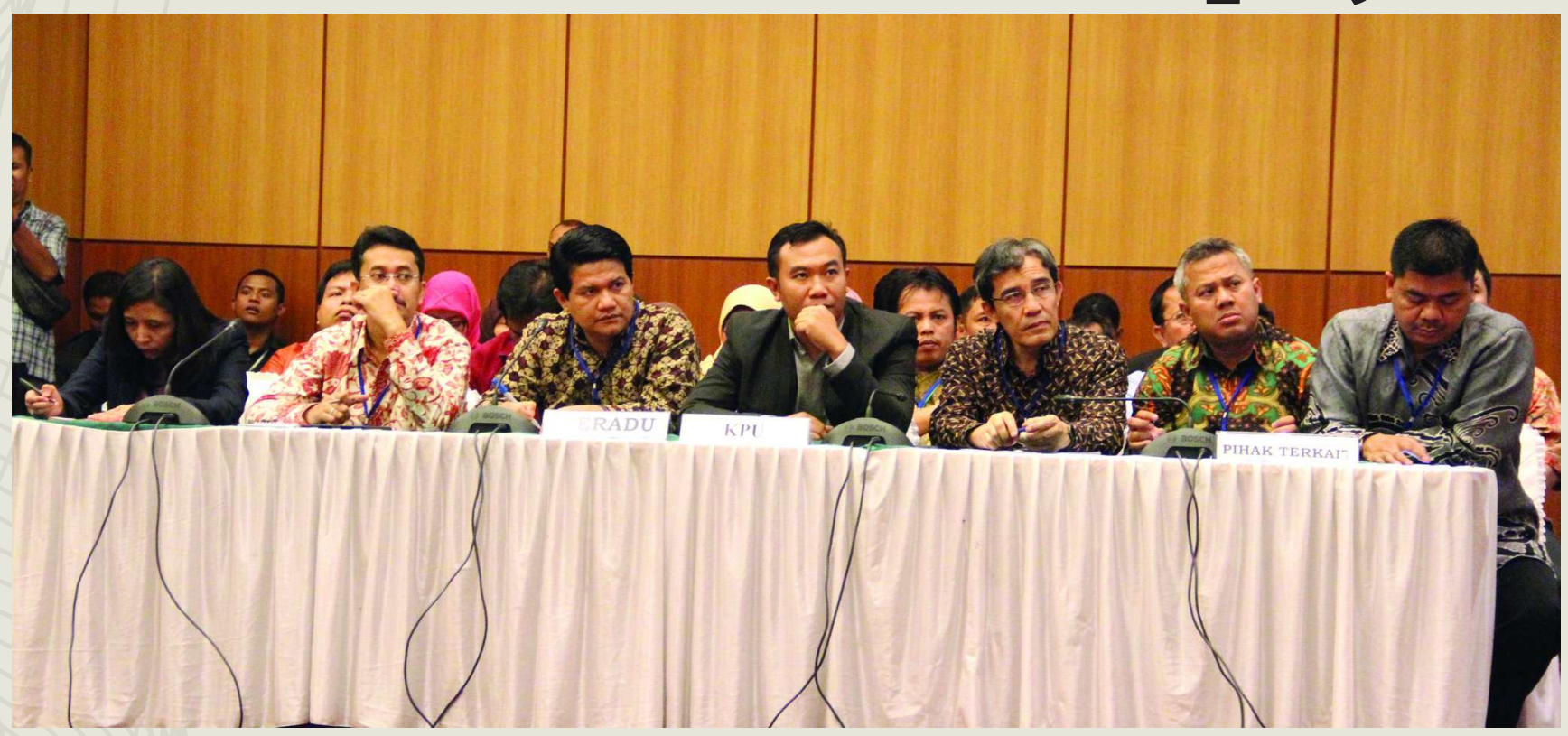

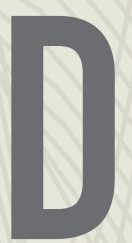

ua keputusan Komisi Pemilihan Umum (KPU) dalam penyelenggaraan Pemilihan Presiden dan Wakil Presiden (Pilpres) 2014 mendapat putusan berbeda dari Dewan Kehormatan Penyelenggara Pemilu (DKPP). Keduanya adalah soal pembukaan kotak suara dan penggunaan daftar pemilih khusus tambahan (DPKTb). Perkara ini semuanya diadukan oleh Tim Pasangan Capres-Cawapres Nomor Urut I Prabowo-Hatta.

Putusan DKPP tersebut dibacakan dalam sidang putusan yang digelar di Gedung KH M Rasjidi, Kementerian Agama RI, Jakarta, Kamis (2I/8). Terhadap pembukaan kotak suara, DKPP menjatuhkan sanksi peringatan kepada tujuh komisioner KPU.

"Menjatuhkan Sanksi berupa Peringatan kepada Teradu I, Teradu II, Teradu III, Teradu IV, Teradu V, Teradu VI, dan Teradu VII atas nama Husni Kamil Manik, Ferry Kurnia Rizkiansyah, Ida Budhiati, Arif Budiman, Hadar Nafis Gumay, Sigit Pamungkas, dan Juri Ardiantoro (Ketua dan Anggota KPU Republik Indonesia), sejak dibacakannya Putusan ini," demikian amar putusan DKPP.

Seperti diadukan oleh Pengadu dari Tim Prabowo-Hatta, soal buka kotak suara berawal dari keputusan KPU mengeluarkan Surat Edaran Nomor I446/KPU/VII/2OI4 tentang Penyiapan dan Penyampaian Formulir Model A5 PPWP dan Model C7 PPWP dan Surat
Edaran No. I449/KPU/VII/20I4 tanggal 25 Juli 2014 tentang Sengketa PHPU Presiden dan Wakil Presiden Tahun 2014. Surat edaran tersebut memerintahkan kepada KPU Provinsi dan Kabupaten/ Kota untuk membuka kotak suara yang tersegel untuk kepentingan perselisihan hasil Pemilu di Mahkamah Konstitusi.

Menurut Pengadu yang diwakili Mahendradatta, keputusan KPU tersebut telah melanggar asas kepastian hukum terutama Pasal I49 UU Nomor 42 Tahun 2008 tentang Pemilihan Presiden dan Wakil Presiden di mana KPU wajib menjaga keamanan semua dokumen yang ada dalam kotak suara. Dalam pertimbangan putusannya, DKPP juga berpendapat bahwa sesuai undangundang dan peraturan KPU, tidak ada kewenangan KPU untuk membuka kotak suara yang sudah tersegel kecuali atas perintah undang-undang.

"Meskipun KPU merupakan 'penguasa kotak suara secara fisik', namun data, dokumen, dan informasi di dalam kotak suara bukan milik KPU, tetapi milik publik sebagai mahkota Pemilu. Kepentingan pemilih (sebagai pihak yang memberikan suara dan peserta Pemilu merupakan suatu nilai dan prinsip yang harus terjaga di dalam kotak suara.

Pembukaan kotak suara baru dapat dilakukan berdasarkan perintah Undang-Undang yakni pada tahapan rekapitulasi dalam rapat pleno terbuka yang dihadiri pihak pengawas, peserta Pemilu, dan saksi," berikut petikan pertimbangan putusan DKPP.
Sedangkan untuk perkara DPKTb, DKPP menilai keputusan KPU sudah tepat. Tidak ada pelanggaran kode etik seperti yang dituduhkan oleh Pengadu. Bahkan DKPP, memuji keputusan KPU atas diberlakukannya DPKTb. Sehingga, tujuh komisioner KPU pun direhabilitasi nama baiknya.

"Menolak pengaduan Pengadu untuk seluruhnya. Merehabilitasi nama baik Teradu I atas nama Husni Kamil Manik, Teradu Il atas nama Ida Budhiati, Teradu III atas nama Sigit Pamungkas, Teradu IV atas nama Arief Budiman, Teradu V atas nama Ferry Kurnia Rizkiyansyah, Teradu VI atas nama Hadar Nafis Gumay, dan Teradu VII atas nama Juri Ardiantoro, selaku ketua dan anggota KPU Republik Indonesia," bunyi amar putusan DKPP.

Dalam sidang putusan ini Majelis dipimpin oleh Ketua DKPP Jimly Asshiddiqie didampingi empat Anggota Majelis yang juga Anggota DKPP, yakni Nur Hidayat Sardini, Saut Hamonangan Sirait, Valina Singka Subekti, dan Anna Erliyana.

Ketua Majelis Jimly Asshiddiqie menegaskan bahwa putusan DKPP bersifat final dan mengikat. Tidak dapat lagi menjadi obyek hukum untuk dipersengketakan di pengadilan mana pun. Suka tidak suka, semua harus menerimanya. Dan seusai sidang, Majelis pun menyalami satu per satu para pihak, baik Pengadu maupun Teradu. 


\section{Keperkasaan Tim DKPP}

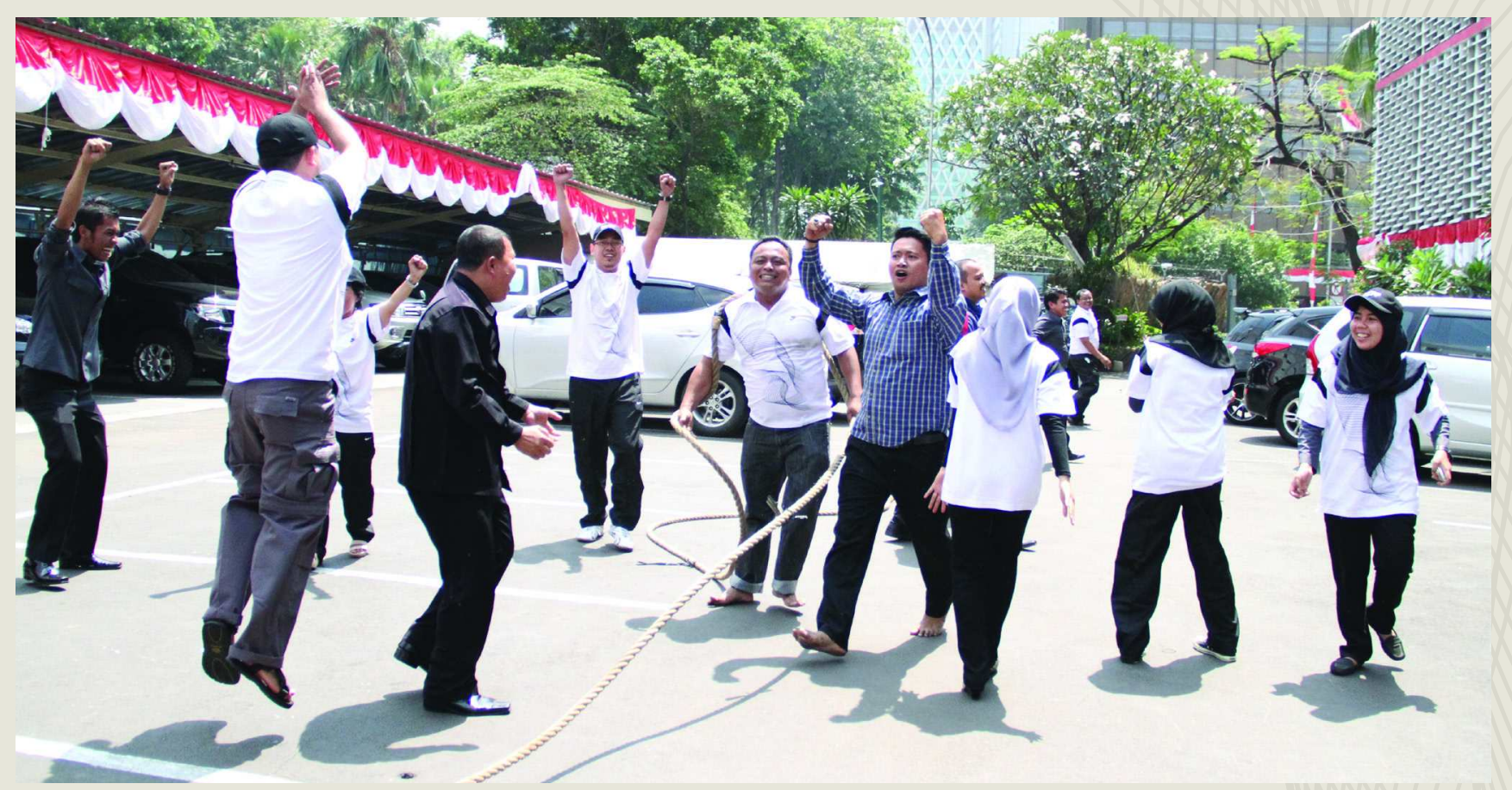

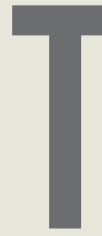

anggal I7 Agustus selalu dirayakan oleh masyarakat di seluruh Indonesia. Pasalnya, pada hari itu merupakan hari yang sangat bersejarah. Pada tanggal itu, Proklamasi dibacakan oleh founding fathers, sekaligus tonggak sejarah kemerdekaan Indonesia. Bangsa Indonesia merdeka dari penjajahan.

Pada tanggal I7 Agustus, masyarakat Indonesia memperingati dengan beraneka cara, terutama dengan beragam perlombaan. Seperti di lingkungan sekretariat Jenderal Badan Pengawas Pemilu (Bawaslu).

Usai melaksanakan apel memperingati hari kemerdekaan, Sekretariat Jenderal Bawaslu menggelar sejumlah perlombaan. Di antaranya, lomba menghias, lomba balap kelereng, lomba makan kerupuk, lomba tarik tambang, lomba bakiak, bulu tangkis dan lain-lain. Lomba ini diikuti antarbiro di lingkungan Sekretariat Jenderal Bawaslu.

Tim dari Biro Administrasi Dewan Kehormatan Penyelenggara Pemilu (DKPP) berhasil menyabet empat juara. Yaitu, lomba tarik tambang kategori putra dan putri, lomba bakiak kategori putra dan putri, lomba balap karung, lomba kelereng dan bulu tangkis kategori putri. Sedangkan bulu tangkis dalam kategori putra, tengah diagendakan final antara Lanugroho/ Teten vs Aceng/Hamid.

Tim putra tarik tambang adalah $\mathrm{T}$ Jefri, staf persidangan, Nurdin, driver kepala Biro Administrasi DKPP, Anggi, office boy, Ahmad Khumaidi, kepala Biro Administrasi DKPP, Rahmat Hidayat, Staf Administrasi Umum DKPP, Zaidi Basiturazak, staf Administrasi Pengaduan, Subhan, staf Administrasi Verifikasi, Titis Aditiyo Nugoroho, kasubbag Verifikasi Administrasi DKPP.

Tim putri tarik tambang, Roma Gultom, staf Persidangan, Dini Yamashita, kabag Administrasi Pengaduan, Hayati Setia Inten, Sespri Bu Valina Singka Subekti, Irmawanti, staf Humas, Susi Dian Rahayu, staf Humas, Esi Nurkesih, kasubbag Protokol, Susi "Ochie" Vusvita, staf Monitoring dan Evaluasi, Hepi Hayati Helmi, staf Monitoring dan Evaluasi DKPP.

Tim putra pada lomba bakiak terdiri diri dari Teten Jamaludin, staf Humas, Subhan, staf Verifikasi Pengaduan, Mutia Purba, Pamdal. Sedangkan Putri, Irmawanti, staf Humas, Susi Dian Rahayu, staf Humas, Umi Nafizah.

Sedangkan perlombaan individu, lomba balap karung dicapai oleh Irmawanti. Lomba balap kelereng yang sabet oleh Hayati Setia Inten. Sementara bulu tangkis putri diraih oleh Susi Vuspita.

Irma bercerita, saat lomba tarik tambang, tidaklah mudah untuk menang. Dia dan timnya harus berusaha sekuat tenaga menarik tim lawan. "Usai narik tambang, kaki saya sampai keram," kata perempuan yang akrab disapa Tayuka itu.

Lain hal dengan yang dialami oleh Hepi Hayati Helmi. Perempuan yang akrab disapa "Eel" itu mengalami luka. Telapak tangannya lecet-lecet. Selain itu, salah satu kukunya tersungkal. "Kuku saya sampai copot hingga berdarah," kata perempuan yang suka musik cadas itu, hal serupa juga dialami Hayati Setia Inten.

Sementara Nurdin, bercerita dirinya tanpa persiapan khusus saat akan mengikuti lomba tarik tambang. Kata dia, kemenangan DKPP ini merupakan yang kedua kalinya. Pada tahun kemarin, dirinya tidak ikut. "Pada tahun kemarin, kawan saya bilang, mengikuti lomba tarik tambang melakukan persiapan khusus, seperti makan telur, olah raga. Saya mah makan ngga ada persiapan khusus. Paginya sebelum tanding makan ketoprak," katanya dengan dialek Betawi. .

Teten Jamaludin 


\title{
Beban Penjara Sebagai Wahana Resosialisasi Narapidana
}

\author{
Oleh Prof. Dr. Jimly Asshiddiqie, S.H., Ketua Dewan Kehormatan Penyelenggara Pemilu RI
}

[bagian kedua dari dua tulisan]

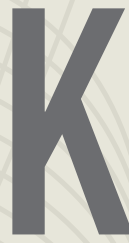

eberadaan sanksi pidana mati dewasa ini semakin banyak dipersoalkan orang di seluruh dunia. Sekarang, semakin banyak negara yang menghapuskan pidana mati karena dianggap tidak lagi sesuai dengan perasaan kemanusiaan global. Akibatnya, orang cenderung menjadikan pidana penjara sebagai andalan utama untuk memberikan sanksi hukuman bagi para pelaku tindak pidana. Pidana penjara dijadikan sarana yang diharapkan efektif mengatasi fenomena kejahatan dan pelanggaran hukum dalam masyarakat.

Padahal, dalam kenyataannya, tingkat kriminalitas dimana-mana juga terus meningkat jumlahnya karena dinamika perkembangan masyarakat di seluruh dunia yang semakin bebas dan kompleks. Dengan sendirinya, karena itu, beban penjara pun menjadi bertambah dan bahkan cenderung menghadapi problem yang sama di mana-mana di seluruh dunia, yaitu kelebihan penghuni atau 'over capacity'. Karena itu, lembaga penjara yang semula dimaksudkan sebagai lembaga koreksi (correctional institutes) atau sarana untuk resosialisasi terpidana, sehingga istilahnya pun sejak tahun I963 diubah dari penjara menjadi lembaga pemasyarakatan, ternyata semakin lama semakin kelebihan beban.

Meningkatnya gejala kelebihan beban hunian ini menimbulkan persoalan berkenaan dengan efektifitas fungsi lembaga koreksi ini dalam praktik. Studi-studi tentang lembaga pemasyarakatan yang dilakukan selama ini, bukan saja di Indonesia tetapi juga di seluruh dunia menunjukkan bahwa fungsi lembaga penjara semakin lama juga dipandang semakin tidak efektif untuk mencapai maksud dan tujuan mulianya semula.

Penjara tidak dengan efektif berfungsi sebagai lembaga resosialisasi atau memasyarakatkan kembali para narapidana ke tengah-tengah masyarakat dengan sekaligus mengoreksi segala kesalahan di masa yang lalu. Sebagian besar mantan napi justru tidak keluar dengan keinsyafan, melainkan justru keluar dengan semangat dendam atau bahkan tidak sedikit yang menjadi ' $r e-$ cidivist' dan bahkan dengan sikap dan keterampilan yang jauh lebih membahayakan bagi kehidupan masyarakat luas.

Dengan perkataan lain, lembaga penjara atau pemasyarakatan terbukti juga tidak efektif untuk dipakai sebagai sarana koreksi dan resosialisasi ke tengah masyarakat. Bahkan, oleh banyak sarjana, lembaga penjara justru malah berkembang menjadi sekolah kejahatan (school of criminals) dan bahkan menjadi pusat atau markas perdagangan narkoba, seperti yang terjadi di Lembaga Pemasyarakatan di Jakarta.

Semua itu terjadi karena perkembangan kriminalitas yang terus meningkat dengan jumlah dan kadarnya yang berkembang sangat cepat, sementara perkembangan daya tampung lembaga-lembaga pemasyarakatan yang ada sangat seimbang, karena tidak diimbangi dengan pembangunan sarana dan prasarana pemasyarakatan secara memadai sesuai dengan

Studi-studi tentang lembaga pemasyarakatan yang dilakukan selama ini, bukan saja di Indonesia tetapi juga di seluruh dunia menunjukkan bahwa fungsi lembaga penjara semakin lama juga dipandang semakin tidak efektif untuk mencapai maksud dan tujuan mulianya semula.

\section{Bung Palu}

Puji syukur kita panjatkan kepada Tuhan yang Maha Kuasa. Betapa tidak, pelaksanaan Pemilu baik Presiden sudah berjalan dengan lancar dan aman:

- Kampanye tak hanya menjual visi dan misi melainkan perang urat saraf di antara dua kubu. Kampanye hitam di mana-mana. Masyarakat pun terpecah menjadi dua blok.

- DKPP sampai menggelar lima kali sidang terkait Pilpres. Siang dan malam. Pelaksanaan sidang ini merupakan sidang terlama. Biasanya, DKPP menggelar sidang hanya satu sampai tiga kali sidang dalam setiap perkara.

- Pemenang Pemilu adalah pasangan Jokowi-Kalla. Ini sebagai pertanda bahwa pasangan ini secara sah menjadi presiden Indonesia terpilih ketujuh.

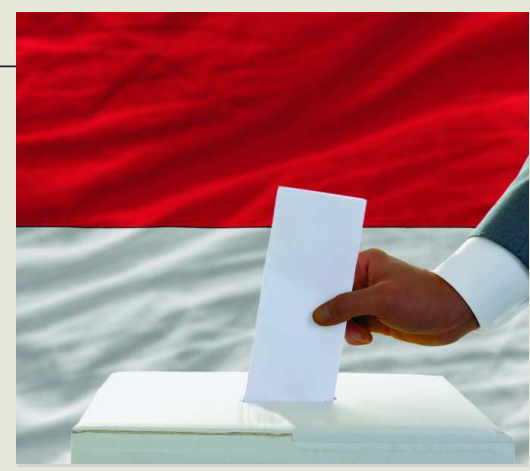




\title{
Kuliah Etika
}

\author{
Rumah Tahanan (Rutan) dan Lembaga Pemasyarakatan (Lapas) di wilayah DKI Jakarta \\ saja tercatat mengalami kelebihan kapasitas penghuni hingga 300 persen.
}

kebutuhan. Akibatnya, semua Rumah Tahanan dan Lembaga Pemasyaraka$\tan$ (Lapas) mengalami kelebihan daya tampung.

Dari data terakhir (20I4), jumlah penghuni Lembaga Pemasyarakatan (Lapas) dan Rumah Tahanan (Rutan) di seluruh Indonesia yang dilansir dalam website Ditjen Pemasyarakatan Kemenhukham, dapat diketahui bahwa Lapas dan Rutan yang tidak mengalami kelebihan penghuni hanya terdapat di 8 provinsi dari 33 provinsi (minus provinsi baru, Kalimantan Utara) di seluruh Indonesia. Ke-8 provinsi itu adalah (i) Papua, (ii) Papua Barat, (iii) Sulawesi Selatan, (iv) Maluku, (v) Maluku Utara, (vi) Sulawesi Barat, (vii) Sulawesi Tenggara, (viii) DI Yogyakarta.

Selebihnya di sebanyak 25 provinsi semua Lembaga Pemasyarakatan dan Rumah Tahanannya semua mengalami kelebihan penghuni, rata-rata sebanyak I48\%. Bahkan di wilayah provinsi Riau saja terdapat kelebihan penghuni Lapas dan Rutan sebanyak $258 \%$, di wilayah DKI Jakarta kelebihan penghuninya mencapai $279 \%$, dan yang tercatat paling parah adalah di Kalimantan Selatan dengan kelebihan penghuni sebanyak 317\%.

Rumah Tahanan (Rutan) dan Lembaga Pemasyarakatan (Lapas) di wilayah DKI Jakarta saja tercatat mengalami kelebihan kapasitas penghuni hingga 300 persen. Bahkan, sampai bulan Juli 20I3-misalnya-Rutan Kelas I Salemba dihuni oleh 3.472 orang, padahal daya

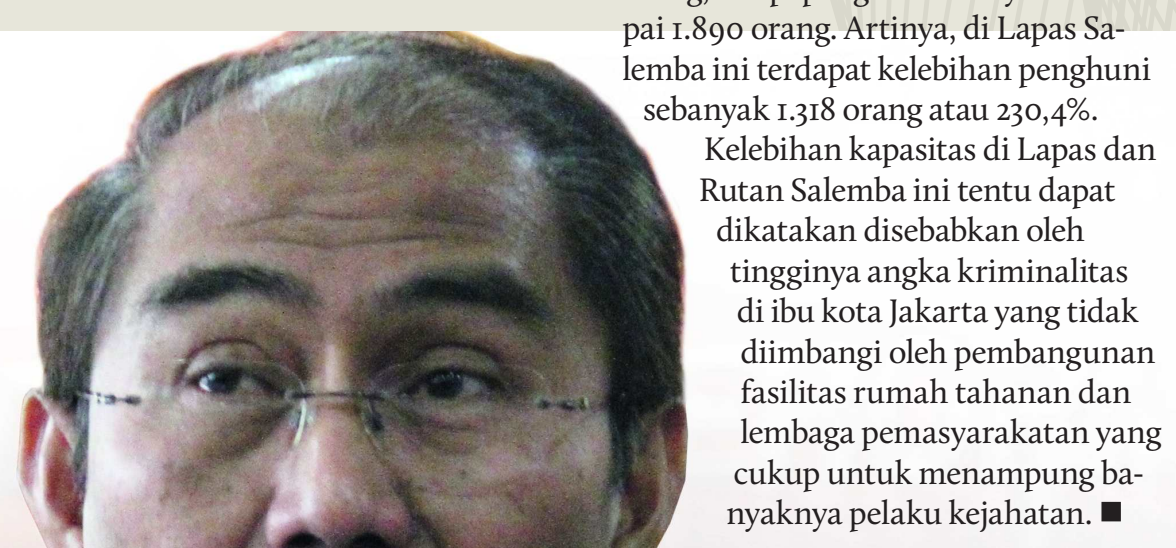

tampung idealnya hanya untuk 880 orang. Artinya, di Rutan Salemba pada tahun 2013 terdapat kelebihan penghuni sebanyak 2.592 atau hampir 300 persen.

Angka kelebihan kapasitas di Rutan Salemba ini sangat fantastis dan tidak masuk akal. Di Lembaga Pemasyarakatan (Lapas) Kelas IIA Salemba, kapasitas hunian tercatat hanya sebanyak 572 orang, tetapi penghuni rielnya mencapai I.89o orang. Artinya, di Lapas Saemba ini terdapat kelebihan penghuni

Rutan Salemba ini tentu dapat dikatakan disebabkan oleh tingginya angka kriminalitas di ibu kota Jakarta yang tidak diimbangi oleh pembangunan fasilitas rumah tahanan dan nyaknya pelaku kejahatan. 


\section{Parade Foto}

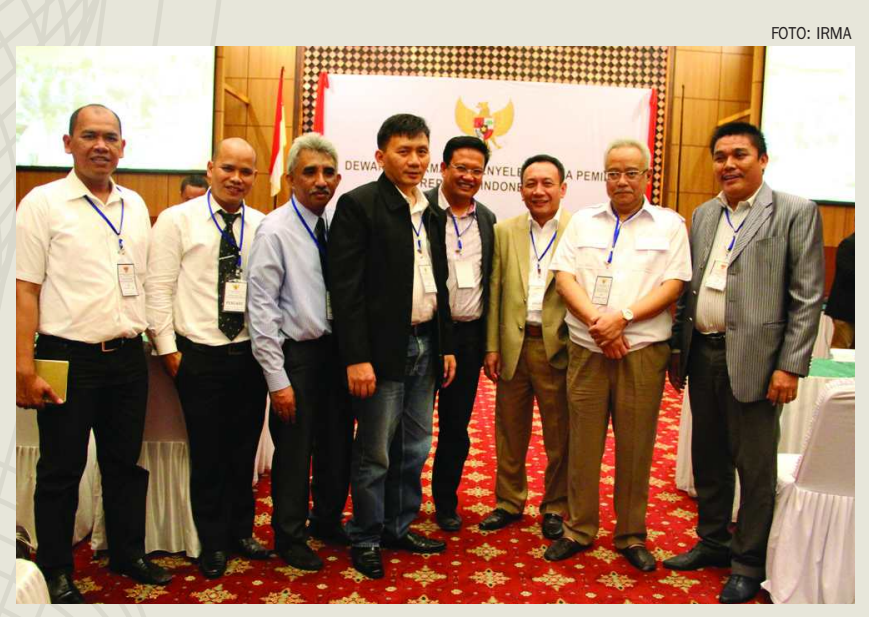

Sebelum sidang Pilpres yang digelar di Kemenag (21/8) dimulai, Pengadu dari Tim Prabowo, Tim Jokowi dan Advokat Independent berfoto bersama.

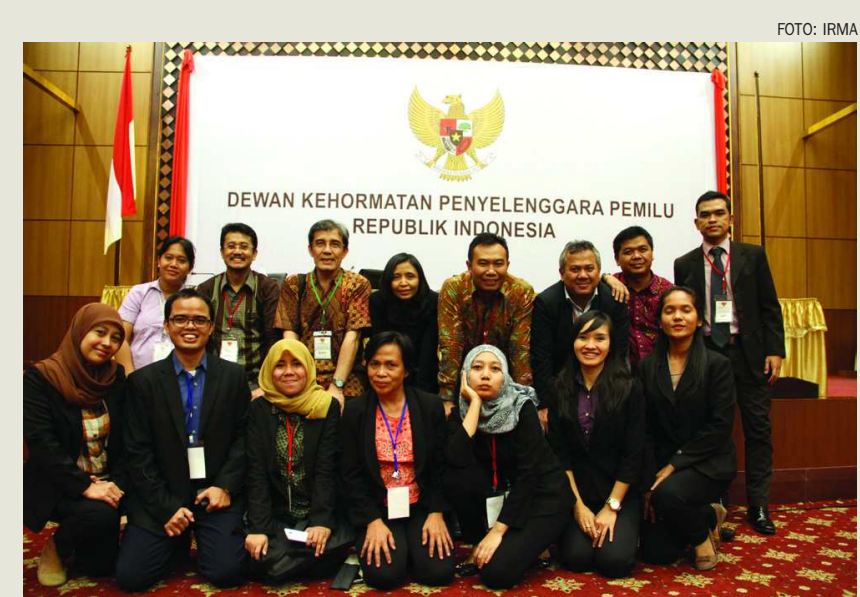

Usai sidang Pilpres di Kemenag (21/8) Anggota KPU RI dan staf DKPP foto bersama.

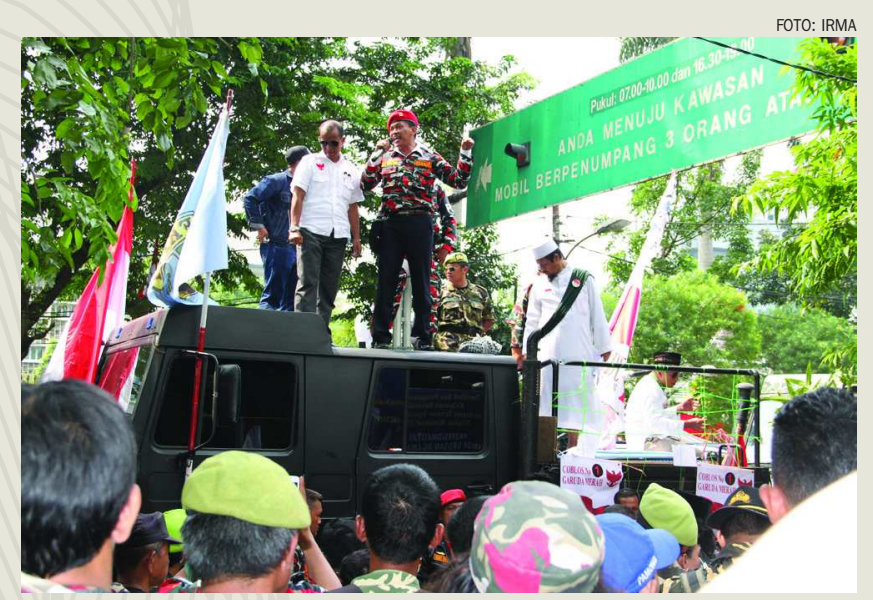

Massa aksi pendukung pasangan Prabowo-Hatta berorasi di depan gedung Kemenag Jumat (25/8) menuntut DKPP untuk adil terhadap perkara yang mereka diadukan

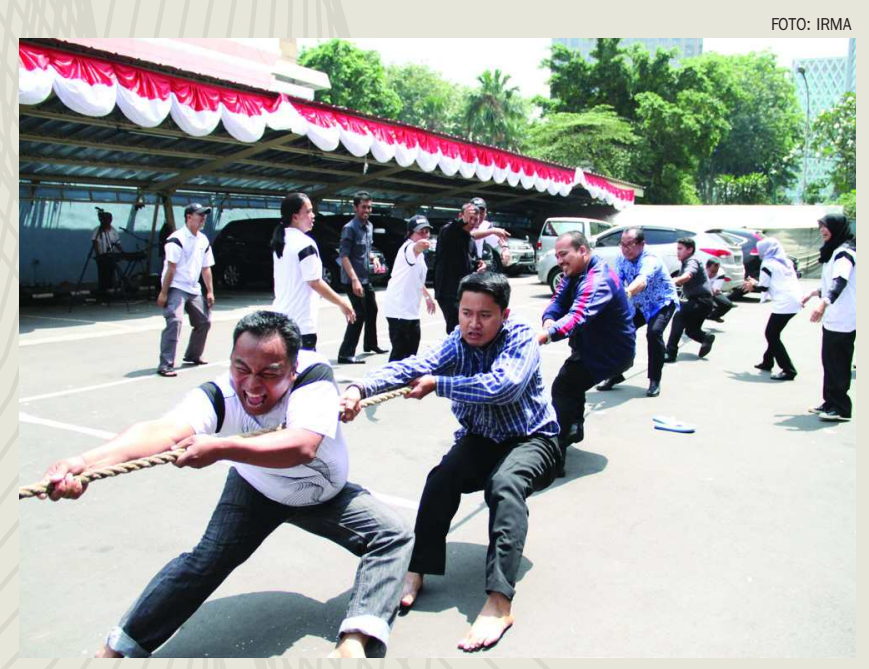

DKPP jadi juara lomba tarik tambang untuk kategori putra dan putri. Lomba diselenggarakan oleh Sekretariat Jenderal Bawaslu dalam rangka HUT RI yang ke-69.

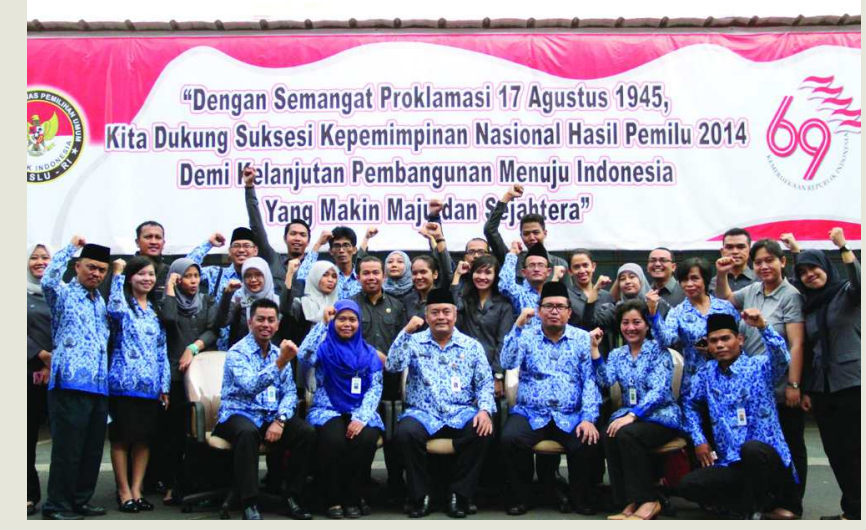

Usai upacara 17 Agustus, Sekjen bersama Karo dan jajaran staf di lingkungan sekretariat DKPP foto bersama.

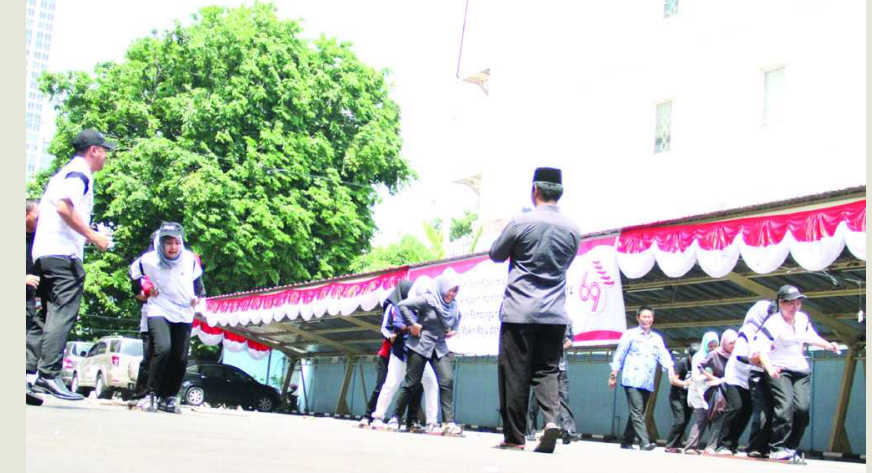

DKPP kembali menjadi juara lomba balap bakiak untuk kategori putra dan putri. Lomba diselenggarakan oleh Sekretariat Jenderal Bawaslu dalam rangka HUT RI yang ke-69. 